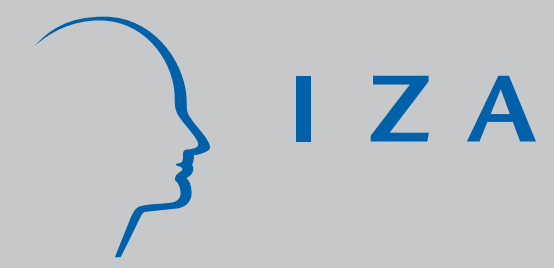

IZA DP No. 640

Dual Track or Academic Route for Auditors: Does It Matter?

J oop Hartog

Nicole J onker

Hans van Ophem

November 2002 


\title{
Dual Track or Academic Route for Auditors: Does It Matter?
}

\author{
Joop Hartog \\ Nicole Jonker \\ De Nederlandsche Bank \\ Hans van Ophem \\ University of Amsterdam \\ Discussion Paper No. 640 \\ November 2002 \\ IZA \\ P.O. Box 7240 \\ D-53072 Bonn \\ Germany \\ Tel.: +49-228-3894-0 \\ Fax: +49-228-3894-210 \\ Email: iza@iza.org
}

University of Amsterdam and IZA Bonn

This Discussion Paper is issued within the framework of IZA's research area Evaluation of Labor Market Policies and Projects. Any opinions expressed here are those of the author(s) and not those of the institute. Research disseminated by IZA may include views on policy, but the institute itself takes no institutional policy positions.

The Institute for the Study of Labor (IZA) in Bonn is a local and virtual international research center and a place of communication between science, politics and business. IZA is an independent, nonprofit limited liability company (Gesellschaft mit beschränkter Haftung) supported by the Deutsche Post AG. The center is associated with the University of Bonn and offers a stimulating research environment through its research networks, research support, and visitors and doctoral programs. IZA engages in (i) original and internationally competitive research in all fields of labor economics, (ii) development of policy concepts, and (iii) dissemination of research results and concepts to the interested public. The current research program deals with (1) mobility and flexibility of labor, (2) internationalization of labor markets, (3) welfare state and labor market, (4) labor markets in transition countries, (5) the future of labor, (6) evaluation of labor market policies and projects and (7) general labor economics.

IZA Discussion Papers often represent preliminary work and are circulated to encourage discussion. Citation of such a paper should account for its provisional character. A revised version may be available on the IZA website (www.iza.org) or directly from the author. 
IZA Discussion Paper No. 640

November 2002

\section{ABSTRACT}

\section{Dual Track or Academic Route for Auditors: Does It Matter?}

In the Netherlands auditors can be trained in a part-time educational track in which students combine working and studying or in a full-time educational track. The former training is relatively firm-specific whereas the latter training is relatively general. Applying human capital theory, we expect higher wage growth for full-time educated auditors than for dual-educated auditors. Furthermore, full-time educated auditors may have better outside options than parttime educated auditors. This may make it easier for them to switch employers than for the part-time educated auditors. The predictions on tenure and wages of differently educated auditors are supported by the estimation results in this paper. The part-time, dual track appears an important route for students from lower socioeconomic background.

JEL Classification: $\quad \mathrm{C} 35, \mathrm{C} 41, \mathrm{~J} 24, \mathrm{~J} 31, \mathrm{~J} 63$

Keywords: $\quad$ human capital formation, mobility, wages, auditors

Corresponding author:

Joop Hartog

Department of General Economics

University of Amsterdam

Roetersstraat 11

1018 WB Amsterdam

The Netherlands

Tel.: +3120525 4298

Fax: +3120 5254254

Email: hartog@fee.uva.nl 


\section{T wo tracks of accountancy training}

Little is known yet about the exects of dixerential tracks in education on productivity of graduates. At best, there is some research on dual tracks in lower vocational training (Van Imhox and Ritzen, 1989; Van der Velden and Lodder, 1995; Plug and Groot, 1998; Sollogoub and UIrich, 1999).To help ..ll this gap, we analyze the dixerences in labor market position for Dutch auditors who graduated from either the academic program or the dual program. Below, we describe the two programs and lay out the plan of this paper.

In the Netherlands, there are two routes to the title "R egister Accountant" , equivalent to the titles" CPA" or "CA" used in Anglo-Saxon countries ${ }^{1}$. The entire academic study (the full-time track) nominally takes 6 years, 4 years as a university student and 2 years as a post-doctoral $^{2}$ student, combining work (four days a week) and studying (some 20 hours week, including going to school one day a week). The NivRA ${ }^{3}$ (or dual or part-time track) nominally takes 7.5 years, working 4 days a week, going to school one day and spending about 12 hours on homework. A cademic students ..rst enjoy university life (studying 30-40 hours a week) and then spend nominally 2 years in combined education and work, totalling some 52 hours a week. NIvRA students live this combined 52 hours a week life for 7.5 years. NIvRA students work in an accountancy ..rm all through their education, from assistant accountant to junior manager to audit manager as they advance through their training program. A cademic accountants only combine work and education in the two year post-doctoral segment. They have to ..nance the ..rst four years in university themselves (or participate in the general government grants and loans program), while the employer will ..nance the post-doctoral part. NIVRA students enjoy employer support all along. Their employers generally pay for tuition, text books and sometimes (part of) the salary for days in school. While working of course they get a salary, initially low relative to other secondary school graduates, but

\footnotetext{
${ }^{1}$ See Vaatstra (1996) for a detailed description (in Dutch) of the accountancy training in the Netherlands. Translation of terminology is not always straightforward. The standard university education is completed with a 'doctoraal' degree, equivalent to a Master's. The graduate obtains the title 'doctorandus' (drs). The 'post-doctoraal' training for accountant would elsewhere perhaps be called a M aster's Degree in A ccountancy. We will try to avoid confusion by refraining from using Anglo-Saxon 'equivalences'. We will use the terms auditor and accountant interchangeably.

${ }^{2} \mathrm{~N}$ ote that 'post-doctoral' is dixerent from 'post-doctorate'. See note 1.

${ }^{3} \mathrm{~N}$ IVRA is the Netherlands Institute of R egistered Accountants.
} 
catching up in about ...ve years.

B oth tracks generate the same level of core professional competences. But full-time students get more of general economic subjects and mathematics their analytical skills may therefore be better developed than those of the graduates from part-time education. Parttime students on the other hand have more training in applying their theoretical knowledge to practical situations. In other words, academic accountants have more general human capital, NIvRA accountants have more job and ..rm speci..c human capital.

W ith the more general human capital of the academic accountant having modest immediate value in the job and assuming the sharing of the bene..ts from speci..c human capital not dramatically dixerent between the two types of graduates, we predict the wage of the NIvRA accountants to be higher at the time of graduation. The more general human capital of the academic accountants, however, is a more fertile basis for further investments. Possibly also, academic students are more inclined to invest; they may have chosen the academic route precisely because they wanted a broader range of investment and career opportunities. Hence, we predict steeper wage growth for the academic accountant, and more job and employer mobility than for the NIVRA accountants. The dixerent characteristics of the two tracks may attract dixerent students in terms of preferences and personality traits.

In the remainder of the paper, we analyse the training alternatives for accountants. In section 2, we introduce the data and a summary of dixerences. In section 3 we will analyze earnings, in 4 tenures and in 5 the time it takes to become a partner, or leave the ..rm, in upor-out contracts common in public auditing ..rms. Section 6 concludes. We have abstained from an attempt to specify an all-encompassing model for education and career choices, as this would be far too complicated econometrically. But we present the separate analyses of earnings, mobility and tenure in one paper rather than spinning out the issues in separate papers. While each analysis by itself may have modest results, they jointly tell a coherent story. To maintain a manageable length of the paper, we have relegated most technical details to Appendices. ${ }^{4}$ M ore details are given in J onker (2001).

\footnotetext{
${ }^{4} \mathrm{~A}$ vailable on our website: $\mathrm{http}: / /$ testweb.fee.uva.nl/ research// pp/ midden 1.asp?id=1
} 


\section{Data and variables}

The data are from a survey held among 3000 auditors in the Netherlands in the period December 1998-February 1999, drawn from the membership roll of the Royal NIvRA (of which every auditor is a member). The auditors in the sample are all working and aged 32-65 years. The lower age limit was chosen to ensure that all respondents had a fair amount of work experience (at 32, fast academic accountants would have ten years of work experience; however, most students need more than the nominal duration to graduate). 1599 individuals have returned their questionnaire. 1523 specify their education: 580 have university training, 717 have dual NIvRA training, 226 have a mixed training. The latter observations have not been used, as it would be too complicated to disentangle the relative contributions of the training types. This leaves us with 1297 observations. In the empirical analyses less observations have been used. This is due to missing variables on dependent variables and explanatory variables and to the exclusion of certain groups in the analyses. In section 3, women have been excluded from the analysis, because hardly any woman makes it to partnership. For symmetry reasons we have also excluded them in the analysis of the employee wages $^{5}$. 813 observations have been used in the wage analysis of employees and information on about 220 partners has been used for the analysis of partner earnings. In section 4 , on tenure durations, 22 self-employed auditors have been excluded and 927 observations have been used in the analysis. In section 5 we have used information on 616 auditors who started working in public auditing. We distinguish employees and employers/partners. Employers operate their own independent business ..rms, partners have been invited to become partner in an accountancy ..rm operated as a partnership.

The respondents represent the population well. A ge, gender, type of accountancy education and work sector of the original sample and the respondents have been compared and there were no indications that the respondents dixer from the auditors in the sample.

Simple analyses (in Appendix A) show that NIVRA accountants are more often from a lower social background (measured by father's education) than academic accountants and had their parental residence farther away from a university. Unconditional earnings do not dixer very much by education. However, job tenures are shorter for academic accountants.

\footnotetext{
${ }^{5}$ However, including women in the wage analysis of employees hardly altered the estimation results.
} 
In public auditing, NIVRA accountants appear more likely to have become a partner in the ..rm they worked for when graduating than academic accountants, who appear more likely to have left the ..rm within our interval of observation.

The respondents were asked to indicate the three most important factors which axected their educational choice. The results indicate that individuals selected themselves into an educational track precisely because of its distinguishing features: broad training and the virtues of academic life for academic accountants, the advantages of working and learning for the NIVRA accountants.

\section{Earnings in 1998}

We estimate earnings equations for employees and partners separately, because the earnings composition is essentially dixerent: partners will receive a share of pro..ts for the ..rm, on top of their monthly wages. Since we are not interested in earnings dixerences between employees and partners, we do not correct for selectivity between these two groups, but instead estimate them separately. We do correct for endogenous educational choice, however, as this is our main theme. The basic econometric model is given in Appendix B. It's a switching regression model, with a probit for type of education and an ordered probit for earnings (reported in intervals). A s we want to know where any dixerences may be located, we estimate three speci..cations. M odel 1 is the full model, with two separate earnings equations and no restrictions on correlation between earnings and education choice. Model 2 speci..es correlation and standard error of earnings to be identical for both educational types and allows for interactions of explanatory variables and education type in the earnings function (the coeф cient for an independent variable is augmented with a dummy term for NIVRA education). Hence, the earnings functions in observables in Model 1 and 2 are identical, except that Model 2 immediately gives a test on the dixerence in coet cients between the two education types. In Model 3, in addition, all coec cients in the two earnings functions are identical, except for a dixerent intercept. The models are estimated for monthly wages of employees, monthly wages of partners/employers and for pro..ts of partners/employers. We excluded some observations with unrealistic or missing values for explanatory variables. Women are also excluded (among employers/ partners, there are only 6 women). 


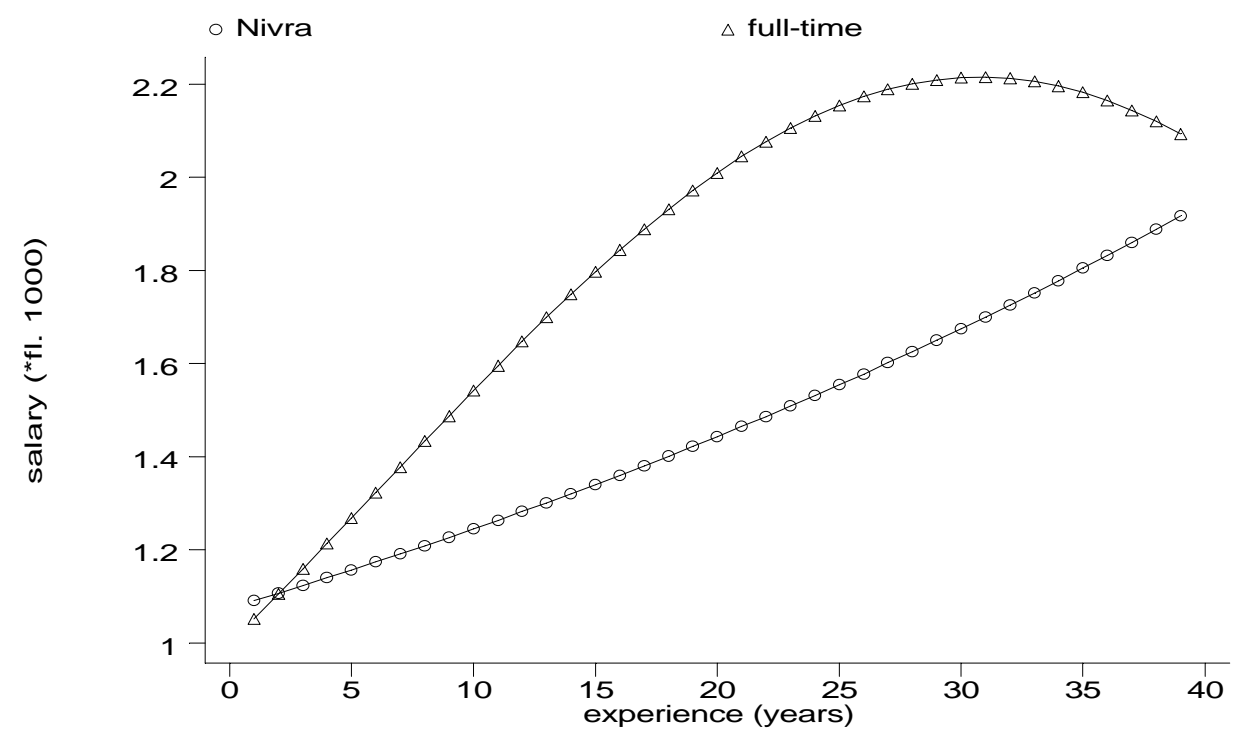

Figure 1: Wage pro..les per educational type

\subsection{Employee monthly wages}

As shown in Table 1, educational choice is signi..cantly axected by the education of the respondent's father. The higher the educational level of the respondents' father the more likely (s)he has attended full-time education. Financial constraints or perhaps socio-cultural barriers may be relevant here. People who in their ..nal year at secondary education have lived more than 10 kilometers from a university with a department of economics are less likely to have chosen for full-time education. A bility (measured by the dummy 'reexamination', i.e. repeated the ..nal exam, at secondary education) or having started the study two years or more after graduating from secondary education (which may be due to drop-out from another education) has no signi..cant exect on educational choice.

In Table 2, we test the three models against each other. The restriction on correlation coel cients and wage dispersions to be equal for both education types has no signi..cant exect and can be accepted (as would also be obvious from the numerical values: they barely dixer). However, restricting all earnings function coec cients to be equal has to be rejected. Hence, Model 2 is the preferred model: parameters of the earnings functions dixer by type of education.

Inspecting the results for M odel 2, we see that experience, its square, In of number of hours 
worked a week, and sector axect employees' wages. Marital status, ...rm size, tenure, having emoluments and working in the $\mathrm{R}$ andstad (cities in the west) do not axect wages signi..cantly. ${ }^{6}$ Experience increases wage at a decreasing rate just as human capital theory predicts. This exect is highly signi..cant for full-time educated auditors. For part-time educated auditors experience has a positive almost signi..cant exect on wages but its square has no exect at all. Figure 1 contains a graph of experience against wage for each educational type, calculated from $^{7}$

$$
\begin{aligned}
& \text { wage }_{f}=\exp \left(\mathrm{i} \text { 0:00084 } \alpha \operatorname{expr}^{2}+0: 0517 \text { a expr }\right) \\
& \text { wage }_{p}=\exp \left(0: 00001 \alpha(\operatorname{expr}+5)^{2}+0: 0145 \propto(\exp r+5)\right)
\end{aligned}
$$

Wage is measured from the moment that full-time educated auditors start with the postdoctoral part of their accountancy training. The nominal duration of the full-time part is 4 years but usually it takes students 5 years to complete it. At that moment part-time educated auditors already have worked for ..ve years. To take this into account, work experience of part-time educated auditors is increased with ..ve years. The curved line corresponds with wage of full-time educated auditors whereas the almost straight line corresponds with wage of part-time educated auditors ${ }^{8}$. Only during the ..rst two years, the wage of part-time educated auditors is higher. Thereafter, full timers climb to a maximum advantage after 22 years. The lower starting wage and higher wage growth for academic accountants is in line with the prediction derived above from the dixerence in general and speci..c human capital. Model 2 shows that the dixerence in experience pro..les is statistically signi..cant.

M onthly wages increase with working hours. The wage elasticity for full-time educated auditors (wage elasticity of 0.92 ) is much higher than for part-time educated auditors (wage elasticity of 0.41 ). The dixerence is signi..cant, but we have no immediate explanation.

\footnotetext{
${ }^{6} \mathrm{E}$ stimating tenure slopes is diф cult because of selective job search and hence endogeneity of tenure. The search process may also bias the experience exects as estimated by OLS, see the discussion in Teulings and Hartog (1998). K ey references are Topel (1991) and A Itonji and Shakotko (1987).

${ }^{7} \mathrm{~T}$ hroughout, we use subscript $\mathrm{f}$ for tull-time and $\mathrm{p}$ for part-time educated.

${ }^{8}$ Full-time educated auditors who are at least 32 years old, may already have 14 years of work experience. It is possible that part-time educated auditors' experience has a quadratic exect on tenure but that this exect can't be captured with the data set used, because there is no information on wages during the ..rst years someone works in accountancy.
} 
Sector of work axects auditors' wages. A uditors working in a non-auditor job in the ..nancial sector earn signi..cantly more than auditors in public accountancy (reference category), some $15 \%$ on average. This probably is due to rent sharing, as pro..ts in the ..nancial sector are structurally at a high level.

The estimated correlations do not dixer signi..cantly from zero. This means that there are no unobserved characteristics that axect both the auditor's selection into an educational regime and the wages in that educational regime. Simultaneous modelling of educational type and wages was not necessary after all and just analyzing the wages with ordered probit would not have led to selection bias in the estimates. 
Table 1

$M L$ results In gross monthly wages employees

(switching regression, ordered probit for earnings intervals)

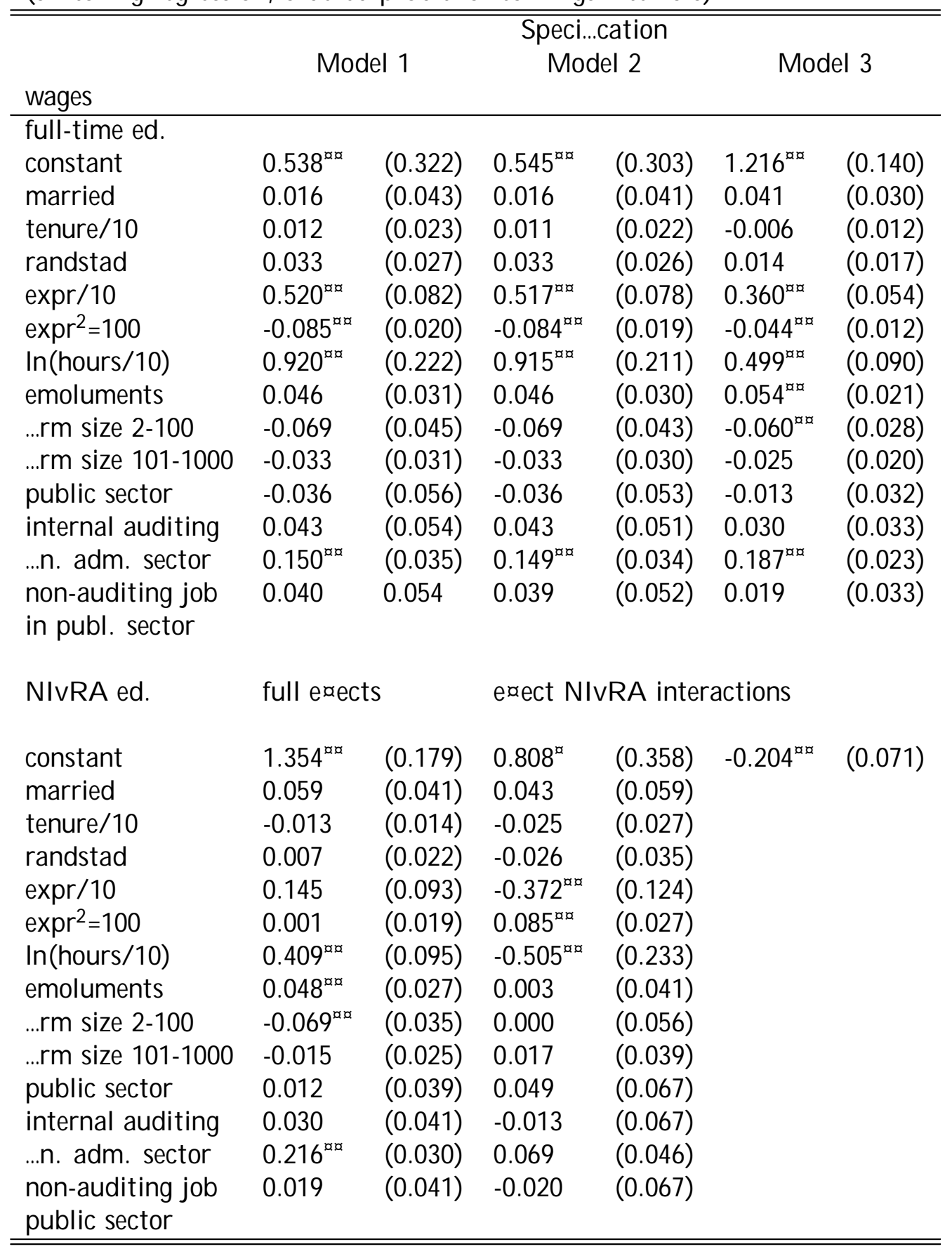


Table 1 continued

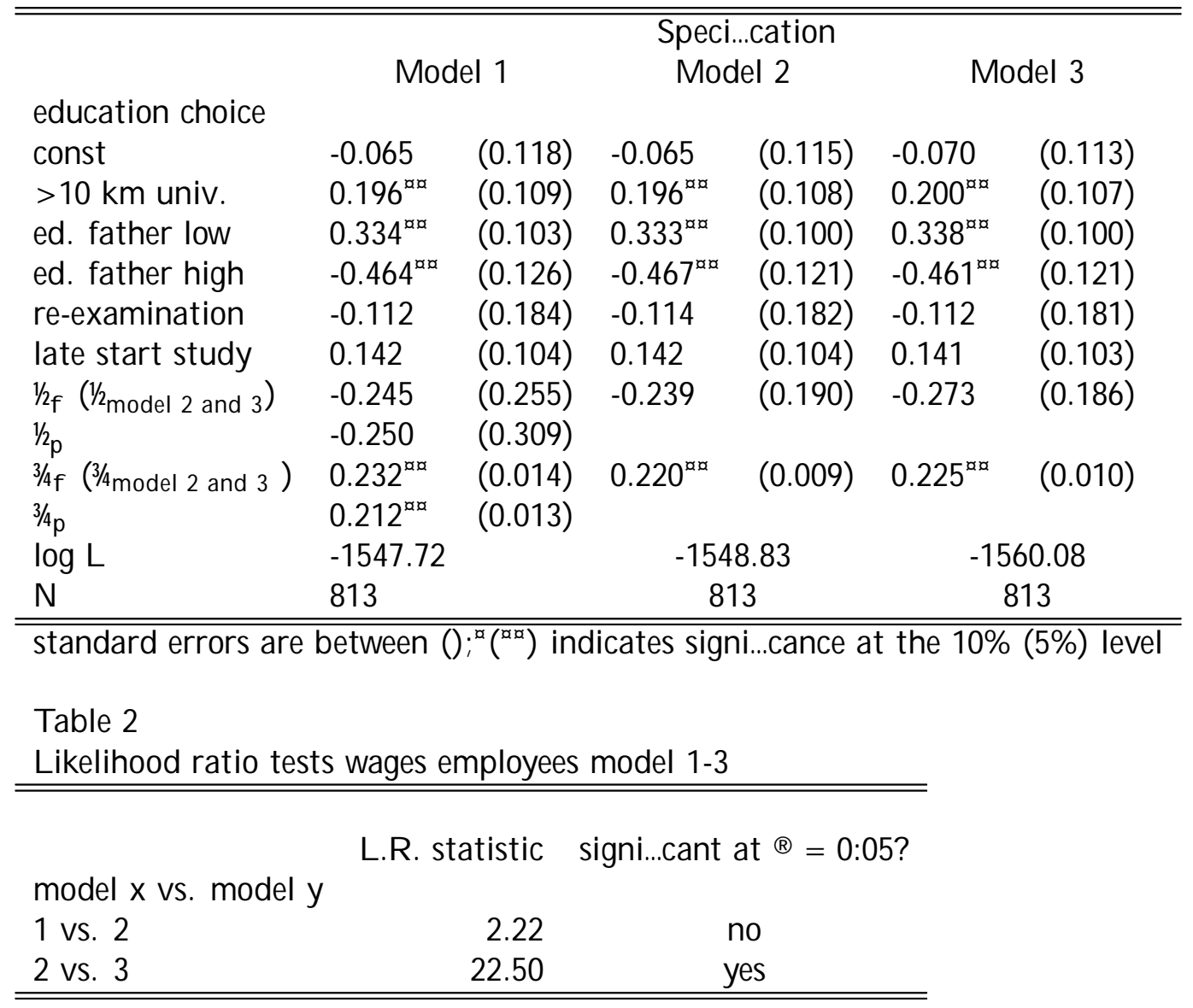

\subsection{Partners'/ employers' monthly wages and annual pro..ts}

Employers and partners ${ }^{9}$ may have two sources of income: ..xed gross monthly salary and pro..ts. Note that per income source there is information on only 250 auditors. Possibly because of the relatively low number of observations it was not possible to estimate the correlation coec cients adequately (they became highly negative) and they have been set to zero. This hardly axected the estimation results. We do not worry about selection bias in the estimated coec cients. ${ }^{10}$

In Table 3 the estimation results on wages and in Table 4 the estimation results on pro..ts are shown. Since the education equation and the income equations are not simultaneously estimated and interest lies in the income equations the estimation results on educational choice are not reported; results did not dixer substantially from those of the employees.

\footnotetext{
${ }^{9}$ In the remainder of this paper the term partners refers to both partners and employers.

${ }^{10} \mathrm{R}$ ecall that the correlation was insigni..cant for employees.
} 
As the test results in Table 5 show, in the model for wages, wage dispersions and coef..cients are not signi..cantly dixerent: the two educational tracks lead to statistically indistinguishable earnings patterns. In the model for pro..ts, the residual dispersions are equal (Model 2 gives no signi..cant loss of ..t), but coeç cients in the earnings function dixer significantly once we have imposed the restriction of equal dispersions and correlations (Model 2 versus Model 3), just as in the model for employees. But here also the dixerences are minor, as can be seen from comparing coet cients and from the lack of signi..cance of interaction terms. The only signi..cant dixerence is in the exect of medium sized ..rms on pro..ts: a strong dip for academic accountants, no exect for NIvRA accountants.

In the wage equation (M odel 3) work experience has no exect. Tenure, sector of work and ..rm size are signi..cant, and so is hours worked (with an elasticity virtually equal to 1 ). In the pro..t equations (Model 2), we also ..nd insigni..cant exects for experience. Hence, for partners both wages and pro..t shares are determined by their tenure, and not by experience. Firm size has a very strong exect and again, hours worked has an elasticity of about 1 . There are few dixerences between the education types: only the negative ..rm size exect for ..rms 11-100 is annihilated for NIvRA graduates. 
Table 3

$M L$ results In monthly wages partners

(switching regression, ordered probit for earnings intervals)

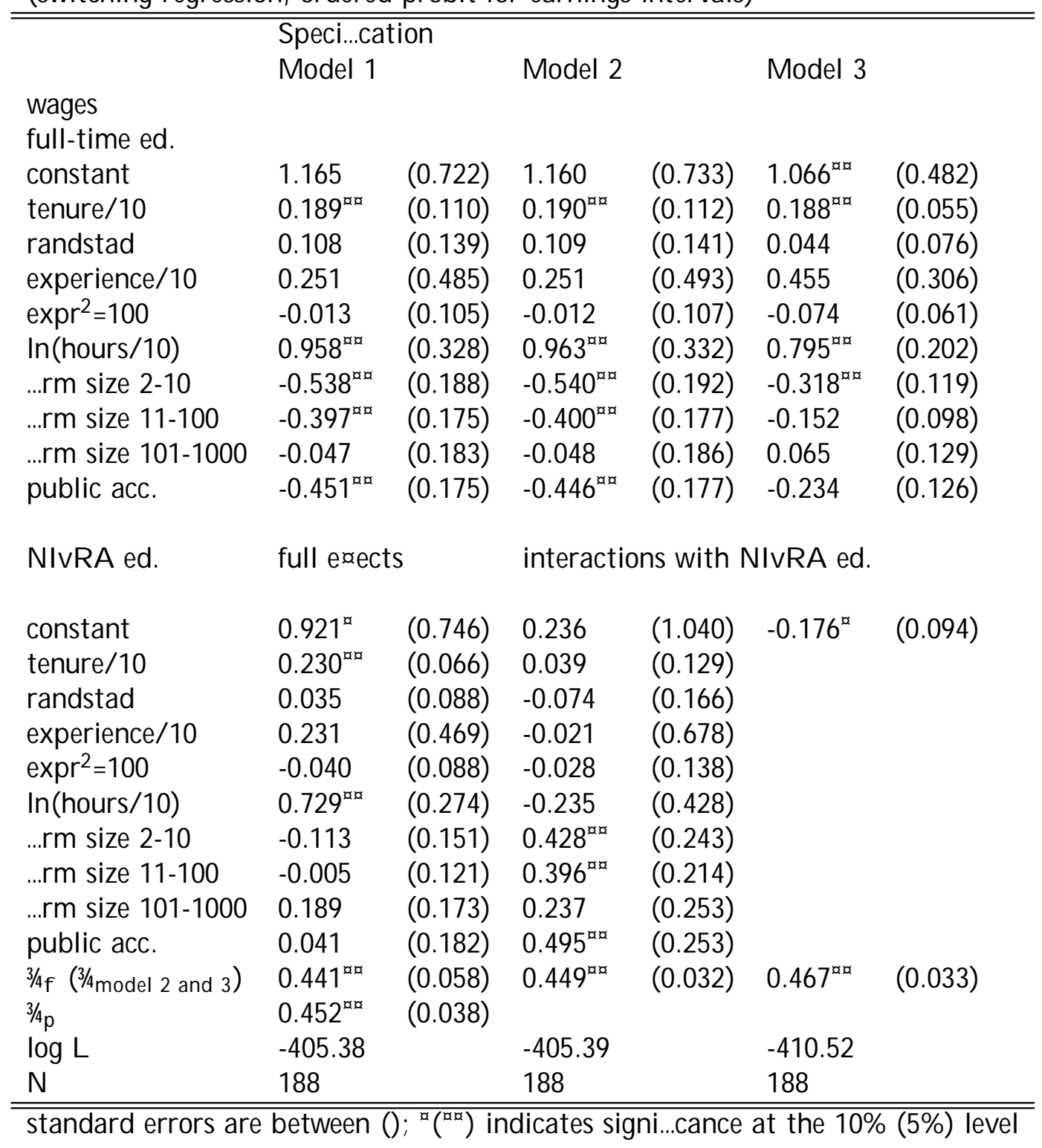


Table 4

ML results In annual pro..t 1997 (switching regression, ordered probit for pro..t intervals)

\begin{tabular}{|c|c|c|c|c|c|c|}
\hline $\begin{array}{l}\text { pro..t } \\
\text { full-time ed. }\end{array}$ & \multicolumn{2}{|c|}{ Speci..cation } & \multicolumn{2}{|c|}{ Model 2} & & Model 3 \\
\hline constant & 0.209 & $(0.927)$ & 0.183 & $(0.964)$ & 0.237 & $(0.526)$ \\
\hline tenure/ 10 & $0.272^{\infty \alpha}$ & $(0.124)$ & $0.274^{\infty x}$ & (0.129) & $0.263^{\infty}$ & $(0.060)$ \\
\hline randstad & 0.088 & $(0.144)$ & 0.089 & $(0.150)$ & 0.079 & $(0.084)$ \\
\hline experience/ 10 & 0.208 & $(0.608)$ & 0.211 & $(0.633)$ & $0.578^{x a x}$ & $(0.325)$ \\
\hline expr ${ }^{2}=00$ & -0.059 & $(0.137)$ & -0.060 & $(0.143)$ & $-0.127^{\infty}$ & $(0.062)$ \\
\hline In(hours/ 10) & $1.003^{\text {axd }}$ & $(0.403)$ & $1.020^{\cos }$ & $(0.418)$ & 0.579 & $(0.211)$ \\
\hline ..rm size $2-10$ & $-0.775^{\infty}$ & $(0.219)$ & -0.779 & $(0.227)$ & $-0.567^{\infty}$ & $(0.136)$ \\
\hline ..rm size $11-100$ & $-0.701^{\infty}$ & $(0.197)$ & $-0.704^{\infty}$ & $(0.210)$ & -0.197 & $(0.112)$ \\
\hline ..rm size $101-1000$ & 0.277 & $(0.200)$ & 0.282 & $(0.208)$ & $0.311^{\infty}$ & $(0.138)$ \\
\hline public acc. & $-0.470^{\infty}$ & $(0.216)$ & $-0.477^{\infty 00}$ & $(0.225)$ & -0.360 & (0.147) \\
\hline NIvRA ed. & full exect & & interactic & ns with I & IlvRA ed. & \\
\hline constant & 0.355 & $(0.775)$ & 0.175 & (1.229) & 0.049 & $(0.102)$ \\
\hline tenure/ 10 & $0.320^{\infty x}$ & $(0.070)$ & 0.045 & $(0.146)$ & & \\
\hline randstad & 0.111 & $(0.099)$ & 0.021 & (0.179) & & \\
\hline experience/ 10 & 0.568 & $(0.506)$ & 0.355 & (0.805) & & \\
\hline $\operatorname{expr}^{2}=100$ & -0.121 & $(0.090)$ & -0.061 & $(0.168)$ & & \\
\hline In(hours/ 10) & 0.329 & $(0.245)$ & -0.692 & $(0.483)$ & & \\
\hline ..rm size 2-10 & -0.049 & $(0.137)$ & 0.421 & $(0.282)$ & & \\
\hline ..rm size $11-100$ & 0.080 & $(0.141)$ & $0.783^{\infty \alpha}$ & $(0.236)$ & & \\
\hline ..rm size $101-1000$ & $0.360^{\infty \alpha a x}$ & $(0.180)$ & 0.078 & $(0.273)$ & & \\
\hline public acc. & -0.278 & $(0.192)$ & 0.201 & $(0.294)$ & & \\
\hline $3 / 4(3 /$ model 2 and 3$)$ & $0.525^{a x}$ & $(0.056)$ & $0.547^{\infty \alpha}$ & $(0.031)$ & $0.571^{\infty x}$ & $(0.033)$ \\
\hline $3 / \oplus$ & $0.556^{\text {ax }}$ & $(0.038)$ & & & & \\
\hline $\log L$ & -500.17 & & -500.27 & & -508.90 & \\
\hline $\mathrm{N}$ & 216 & & 216 & & 216 & \\
\hline
\end{tabular}

Since in the pro..t model, reduction of Model 2 to Model 3 was statistically rejected, we calculated pro..ts to see the magnitude of the educational dixerential. As Table 6 indicates, using educational category averages for explanatory variables and coec cients from Model 2, predicted pro..ts are highest for full-time educated partners in the full-time regime immediately followed by the predicted pro..ts of part-time educated partners in their regime. The pro..t dixerential is negligible: $D \neq 1,186$ or $0.4 \%$ of the predicted pro..t of full-time educated partners. Combining this with the ..nding that wages of NIvRA partners do not dixer significantly from academic partners indicates that there is no evidence that type of accountancy training aqects total income of partners. 
Table 5

Likelihood ratio tests employers/ partners

\begin{tabular}{lccll}
\hline \hline & monthly wages & pro..ts & \\
& L.R. statistic & signi..cant at & L.R. statistic & signi..cant at \\
& & $\circledR=0: 05 ?$ & & $\AA=0: 05 ?$ \\
model 1 vs. 2 & 0.02 & no & 0.20 & no \\
model 2 vs. 3 & 10.26 & no & 17.26 & yes \\
\hline \hline
\end{tabular}

Table 6

Predicted conditional pro..ts $(* D \ddagger 10,000)$

education attended

NIVRA full-time

pro..t regime

NIVRA $\quad 31.08 \quad 30.04$

full-time $\quad 27.34 \quad 31.19$

\subsection{Conclusion on earnings}

We can draw a strong conclusion. For employee wages we ..nd a dixerence in experience pro..les and in hours elasticities. Academic accountants start lower but grow faster, corroborating a prediction based on their greater initial stock of general human capital. The hours elasticity for academic accountants is not dixerent from 1, and the elasticity for NIVRA accountants is only half that value. Accountants signi..cantly bene.t from working in the ..nancial-administrative sector, but the exect does not dixer by education. For partner's pro..ts we ..nd a dixerential impact of only one ..rm size category. Otherwise, there is no difference in earnings among graduates from the two educational tracks, neither in observables nor in unobservables. Clearly, in the allocation and selection processes that govern election to partnership, type of training is wiped out as a distinctive characteristic.

\section{Tenure}

To create a good dataset for analysis of tenure durations, we select individuals whose tenure in their 1990 ..rm was known. We added the observation interval 1990-1998 to get data on completed tenure durations. We excluded people who are self-employed and have less than 10 employees at J anuary 1990. This resulted in 927 observations. In this sample 225 auditors have a NIVRA education and a completed 1990 tenure, 219 auditors have a full-time training 
and a completed 1990 tenure, 284 auditors have a NIvRA education and work at the same employer as at J anuary 1990 and there are 169 auditors with a full-time training and who still work at the same employer as at J anuary 1990.

We estimate a simultaneous model for educational choice and tenure duration, as speci..ed in A ppendix C. To deal with endogenous educational choice we apply a method discussed in Lee (1983) and developed in Van Ophem and J onker (1997). This method allows to correct for self-selection in a duration model for any distribution of the error term in the selection equation and for any distribution of the duration. We simplify the joint distribution of the error term of the selection equation and the duration by transforming univariate distribution functions to standard normal variables. The joint distribution of the transformed variables has a bivariate standard normal distribution which is easy to deal with in extensions.

For the tenure distributions we apply the Burr-distribution (Lancaster, 1990, p. 68). It allows for both monotonous and non-monotonous hazards and is analytically tractable and it can deal with unobserved heterogeneity in the sample. Lancaster shows that if one assumes that the hazard rate and the integrated hazard function contain a multiplicative individual speci..c random term $v$ which follows a $i\left(1 ; 3^{2}{ }^{2}\right)$ distribution such that, $\left.(\mathrm{t} ; \mathrm{v})={ }^{1}, \mathrm{t}\right) \mathrm{v}$ and $z(t ; v)=z(t) v$ and if one assumes that the integrated hazard has the speci..cation $z(t)={ }^{\circ} t^{\circledR}$ $(\circledR \triangleright=0$ ); then one gets a Gamma mixture of Weibull distributions which is called the $\operatorname{Burr}\left({ }^{\circ} ;{ }^{\circledR},{ }^{\prime}\right)$ distribution with ${ }^{\prime}=3 / 42$ :

The Burr distribution has the following cumulative distribution, density and hazard function:

$$
\begin{aligned}
& F(T)=1 i^{i} 1+3 / 4 \circ T^{\circledR} \phi_{i}, \\
& f(T)=\frac{{ }^{\circledR}{ }^{\circledR} T^{\circledR 1}}{\left(1+3 / 4^{\circ} T^{\circledR}\right)^{\prime}+1} \\
& \text {, }(T)=\frac{{ }^{\circledR} \mathrm{B}^{\circledR}{ }^{\circledR} 1}{\left(1+3 / 4^{\circ} T^{\circledR}\right)}
\end{aligned}
$$

with ${ }^{\prime}=3 / 4^{2}$ : For $\AA>1$ the hazard function ..rst increases with duration and then decreases. For $0<=®<=1$ the hazard function decreases with duration. The Burr distribution has the Log-Logistic distribution (non-monotonous hazard, 3/4 = 1), the Weibull distribution (monotonous hazard function, $3 / 4=0$ ) and the exponential distribution (constant hazard 
function, $3 / 4=0$ and $®=1$ ) as special cases. In order to relate the exect of the individual speci..c explanatory variables to the duration of tenure we adopt the often used assumption ${ }^{\circ}=\exp \left(\mathbf{X}_{\mathbf{i}^{-}}{ }^{-}\right)$; where $\mathrm{X}_{\mathrm{i}}$ is a vector storing the values of the explanatory variables of individual i.

Table 7 gives the estimation results. In the educational choice equation, starting late now signi..cantly stimulates part-time education, which is understandable as older students may have a family to support, or may have given up another study with less promising perspectives. The very few women in the sample make no signi..cantly dixerent choice.

The estimated correlations between education and tenure are signi..cant at a $10 \%$ level. Correlation between the error term in the education equation and tenure is strong and negative for part-time educated auditors, while for full-time educated auditors it is positive and signi..cant at $10 \%$ but not at $5 \%$. This implies that part-time educated auditors have a longer tenure than the average auditor would have had in case of part-time education and the full-time educated auditors have a shorter tenure than the average auditor would have had in case of a full-time education. The estimates of the ${ }^{\circledR S}$ are signi..cantly higher than 1 indicating that the hazard of changing employer is non-monotonous in time as is also clear from observing tenure distributions and $\mathrm{K}$ aplan-M eier survivor functions ( $\mathrm{A}$ ppendix $\mathrm{A}$ ). Furthermore, the heterogeneity terms ${ }^{\prime} j_{j} j=p, f$ are highly signi..cant indicating that there is unobserved heterogeneity in the sample. But the ${ }^{\circledR} S$ S and ' $q_{S}$ are not signi..cantly dixerent across educations.

A Hausman test on equality of all coeф cients in the tenure equation (intercepts excluded) cannot reject equality $\left(\hat{\mathrm{A}}_{12}^{2}=7.571\right)$ but a test on equality only of signi..cant coeф cients rejects this equality $\left(\hat{A}_{8}^{2}=102.541\right)$.

To facilitate interpretation we calculate the exect of the explanatory variables on the logarithm of the expected duration:

$$
\frac{@ n\left(E\left(T_{j}\right)\right)}{@ X_{i j}}=i \frac{-}{\circledR} ; j=p ; f
$$

In the tenure equations, the signs of coed cients are mostly the same for the two education types, but magnitudes dixer. Part-time educated auditors with children stay longer than auditors without children. Number of years of previous work experience has a "u-shaped"- 
exect on tenure indicating that the length of previous experience ..rst decreases tenure but after a turning point has a positive exect. In all sectors workers have a longer tenure than in public accountancy, the reference sector. This may be the result of the 'up-or-out' culture in this sector which reduces tenure (and which we will analyze below). J ob level (a ranking in ..ve intervals, rank 5 for top level) seems to axect tenure negatively but this exect is not signi..cant. ${ }^{11}$ Only part-time educated auditors who start in job level 3 (senior executive/ middle management) stay signi..cantly shorter than employees who started as assistant accountant. Part-time educated auditors who were still studying when they started working at the 1990 employer do not dixer in tenure from auditors who were auditor when they became employed.

There are few variables axecting tenure of full-time educated auditors; only gender (which didn't play a role in explaining tenure of part-time educated auditors), experience and not having graduated yet have a signi..cant exect. Women stay shorter than men. Experience has a negative and signi..cant exect on tenure and its square has a positive and signi..cant exect. So there is a "u-shaped' exect of experience on tenure just as with the part-time educated auditors. Full-time educated auditors who were still studying accountancy when they started working at the 1990 employer stay signi..cantly shorter than auditors who had already ..nished their accountancy training when they became employed. J ob level and sector have no signi..cant exect.

\footnotetext{
${ }^{11} \mathrm{~J}$ ob titles in the survey have been grouped together by level of job complexity and job requirements. 1 includes jobs performed by accountancy students, 2 is for recent accountancy graduates, mostly executive, 3 is senior executive and middle management, 4 is higher management, 5 is partners, directors in civil service and the private sector.
} 
Table 7

ML estimation results tenure model (Van Ophem and J onker; Burr distribution)

\begin{tabular}{|c|c|c|c|c|}
\hline \multirow{2}{*}{$\begin{array}{l}\text { variables } \\
\text { tenure equation }\end{array}$} & \multicolumn{2}{|c|}{$\begin{array}{l}\text { part-time education } \\
T: i^{-}={ }_{p}\end{array}$} & \multicolumn{2}{|c|}{$\begin{array}{l}\text { full-time education } \\
{\mathrm{T}: \mathrm{i}^{-}}_{\mathrm{f}}={ }_{\mathrm{q}}\end{array}$} \\
\hline & & & & \\
\hline constant & $2.814^{\infty}$ & $(0.288)$ & $2.815^{\infty}$ & $(0.708)$ \\
\hline female & -0.004 & $(0.288)$ & $-0.663^{x x}$ & $(0.263)$ \\
\hline children =1 & $0.431^{\infty}$ & $(0.179)$ & 0.297 & $(0.242)$ \\
\hline experience/ 10 & $-0.681^{x}$ & $(0.376)$ & $-1.660^{\infty}$ & $(0.798)$ \\
\hline experience $^{2}=100$ & $0.271^{\propto}$ & $(0.144)$ & $0.879^{a \alpha}$ & $(0.418)$ \\
\hline public sector/ research & $0.368^{\infty}$ & $(0.172)$ & 0.353 & $(0.291)$ \\
\hline internal auditing & 0.529 & $(0.218)$ & 0.201 & $(0.262)$ \\
\hline ..nancial sector & 0.253 & $(0.175)$ & 0.171 & $(0.195)$ \\
\hline job level 2 & $-0.464^{\infty}$ & $(0.260)$ & -0.049 & $(0.193)$ \\
\hline job level 3 & $-0.674^{\infty}$ & $(0.291)$ & -0.198 & $(0.272)$ \\
\hline job level 4 & $-0.739^{a}$ & $(0.381)$ & 0.045 & $(0.338)$ \\
\hline job level 5 & -0.148 & $(0.365)$ & 0.609 & (0.508) \\
\hline $\begin{array}{l}\text { not graduated } \\
\text { education equation }\end{array}$ & 0.230 & (0.198) & -0.498 & $(0.231)$ \\
\hline constant & & 0.003 & $(0.099)$ & \\
\hline female & & -0.228 & $(0.207)$ & \\
\hline$>10$ km university & & $0.196^{\infty x}$ & $(0.096)$ & \\
\hline education father low & & $0.244^{\infty}$ & $(0.090)$ & \\
\hline education father high & & $-0.394^{\infty}$ & $(0.110)$ & \\
\hline re-examination & & 0.173 & $(0.190)$ & \\
\hline started late & & $0.183^{\alpha}$ & $(0.102)$ & \\
\hline \multicolumn{5}{|c|}{ Parameters Burr distribution } \\
\hline $\mathbb{R}_{\mathrm{p}} ; \mathbb{R}_{\mathrm{q}}$ & $2.283^{\infty}$ & $(0.306)$ & $2.309^{m \alpha \alpha}$ & $(0.291)$ \\
\hline$p ; i_{f}$ & $0.198^{\infty}$ & $(0.060)$ & $0.232^{\infty a \alpha}$ & $(0.079)$ \\
\hline $1 / 3 ; 1 / 2$ & $-0.591^{20 \alpha}$ & (0.171) & $0.447^{\alpha}$ & $(0.231)$ \\
\hline $\log L$ & -2528.73 & & & \\
\hline $\mathrm{N}$ & 927 & & & \\
\hline
\end{tabular}

As Figure 2 shows the hazard rates are non-monotonous and have their peaks at about 9 years for the part-time educated and 5 years for the full-time educated. The estimated hazard rate is higher for the full-time educated auditors than for the part-time educated auditors, especially for the ..rst ten years. The survivor function of the full-time educated lies below the survivor function of the part-time educated, and declines much sharper during the ..rst ten years. This means that full-time educated auditors stay shorter at a given ..rm than 

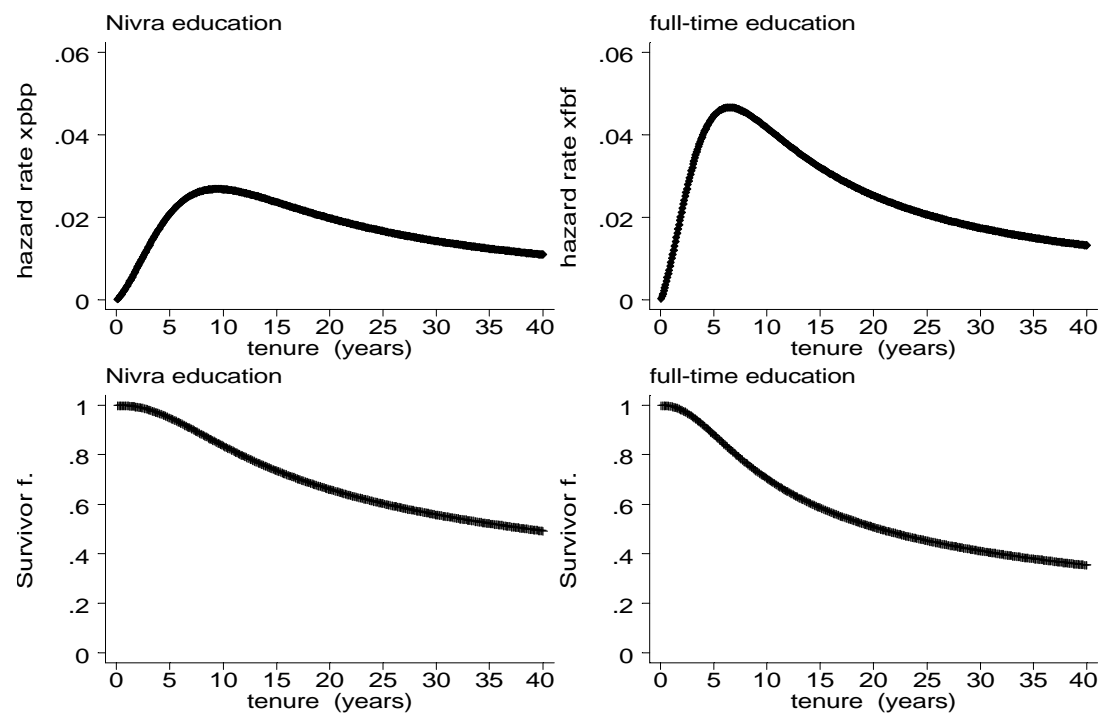

Figure 2: Estimated hazard rates and survivor functions

part-time educated auditors. A ccording to Table 7 the duration dependence parameters ${ }^{\circledR}$ $(j=p, f)$ are not signi..cantly dixerent from each other and the same holds for the heterogeneity terms ${ }_{j}(j=p, f)$. Dixerences in hazard rates must stem from dixerences in the ${ }_{j}{ }_{j}$ 's which are related to the personal characteristics of the auditors: ${ }^{\circ}{ }_{j}=\exp \left(\mathbf{X}_{\mathrm{j}}{ }_{\mathrm{j}}\right)$ : B oth the values of the explanatory variables $X_{j}$ and the tenure coec cients ${ }^{-}$jay cause dixerences in ${ }_{j}$ : It was already noted that the signi..cant variables in the tenure equations are statistically dixerent. In Table 8, we list the average ${ }^{\circ}$ j's (for each educational type j), calculated with the characteristics of both part-time and full-time educated auditors. The average ${ }^{\circ}{ }_{j}$ dixer by educational type (i.e. ${ }^{-}$j) but they do not dixer by the personal characteristics of the dixerent educated auditors. For both types of students the average value of ${ }_{p}^{\circ}$ equals about 0.0015 and the average value of ${ }^{\circ}$ equals about 0.004 . The dixerence in hazard rates (and survivor functions) shown in Figure 2 stem from dixerences in estimated coet cients in the tenure equation ${ }^{-} \mathrm{j}$ and not from dixerences in the personal characteristics of the dixerently educated auditors. 
Table 8

A verage ${ }^{\circ}$ 's for each education type

\begin{tabular}{lll} 
& ${ }_{p}=\exp \left(X_{i}{ }^{-} p\right.$ & ${ }_{f}=\exp \left(X_{i}{ }^{-}\right)$ \\
variable matrix & & \\
$X_{p}$ & 0.001596 & 0.004030 \\
$X_{f}$ & 0.001504 & 0.003961 \\
\hline \hline
\end{tabular}

We end up with the conclusion that academic and NIvRA accountants are not very dixerent in observable characteristics. There is de. nitely unobserved heterogeneity in each education group, but the heterogeneity parameters are not signi..cantly dixerent. Correlation among unobservables magni..es tenure dixerences. A NIvRA auditor has longer than average tenure than an academic auditor would have had, an academic accountant has shorter than average tenure than a NIVRA accountant would have had. Their behaviour is remarkably dissimilar. The coec cients in the duration equation are de..nitely not identical. The clear evidence of shorter expected tenures for academic accountants supports the hypothesis that more general human capital emanating from a broader training prepares them for a higher degree of job mobility. Considering the dixerences in coeł cients in the duration equation, we can identify some factors that contribute to longer durations as NIvRA auditor than as academic auditor: being a woman, having a child, have short prior experience, work in internal auditoring, initial observation at job level below 4. Short experience and low job level point to early career stages, indicating that in advanced career stages, dixerences between NIvRA and academic tenures are smaller.

\section{Up-or-out}

Most ..rms, in particular the large ..rms, in public accountancy are characterized by the 'upor-out' policy for their accountancy employees. Auditors initially working for the ..rm can leave their state in two ways: become partner or leave the ..rm. From our dataset, we selected auditors who were working in public auditing in 1990 and for whom tenure in the ..rm at that time was known. We eliminated some implausible observations. This left us with 280 university trained and 336 NIVRA trained auditors.

De.ne $T_{p}$ as the time until becoming partner and de.ne $T_{1}$ as the time until leaving the accounting ..rm, both measured from the time someone has ..nished his accountancy 
training (auditors provide information from graduating until leaving public accountancy as employee/ non-partner, so the starting date dixers across auditors). We measure $T$ in experience rather than in tenure as we are not interested in what happens in the particular ..rm (hence, we don't condition on being with a particular ..rm) but we are interested in the career of the auditors, and the time they need to make it to partnership. Either $T_{p}$ is completed (i.e. an auditor becomes partner) or $\mathrm{T}_{\text {I }}$ (if an auditor leaves the ..rm), or the auditor is still working as employee in December 1998, when the survey was sent. In an 'up-or-out ' ..rm, longer tenure at the ..rm indicates how well someone performs. A uditors who leave the ..rm relatively early may be the ones who have a low chance of becoming partner of this ..rm. Therefore, as $T_{p}$ and $T_{\text {I }}$ may be negatively correlated, a dependent competing risks model is most appropriate. The analysis is restricted to estimating separate duration models for each educational track in auditing and neglecting educational choice, as the small dataset does not permit a more complicated structure.

The econometric speci..cation of the model is given in A ppendix D. As in section 4, we apply the model proposed by Lee (1983) and developed in Van Ophem and J onker (1997). This method is more general than the semi-parametric model, developed by Han and Hausman (1990); their approximation of a bivariate type I extreme value distribution by a bivariate normal distribution was shown to be of poor quality by Sueyoshi (1992).

The estimation results for the full-time accountancy training and the NIVRA accountancy training are shown in Table $9 \mathrm{~A}$ respectively Table $9^{12}$. To test structural dixerences by education, a single duration model was estimated on both NIvRA and full-time educated

\footnotetext{
${ }^{12}$ Models which allow for unobserved heterogeneity were also estimated by extending $\mathrm{i} \ln \left(\not_{0 \mathrm{mn}}\left(\mathrm{T}_{\mathrm{mn}}\right)=\right.$ $\mathrm{X}_{\mathrm{jm}}{ }^{-}{ }_{\mathrm{mn}}+{ }^{\mathrm{m} n}$ with an error term " $\mathrm{mn}$ :

$$
\mathrm{i} \ln \left(\not_{0 m n}\left(T_{m n}\right)=X_{j m}{ }^{-} m n+"{ }_{m n}+»_{m n}\right.
$$

Both a full parametric ( ${ }_{m n}$ following the normal distribution) and a semiparametric speci..cation (see Van Ophem and J onker, 1997, p. 19) of "mn have been used. With both speci..cations the estimated ${ }^{-} \mathrm{mn}$ 's and their signi..cancy were much alike the estimation results shown in table $9 \mathrm{~A}$ and $9 \mathrm{~B}$. It is not clear whether there is unobserved heterogeneity present in the model or not. When assuming the normal distribution some heterogeneity parameters dixered signifcantly from zero but in case of a semiparametric speci..cation the heterogeneity parameters were not signi..cantly dixerent from zero. However, correcting for unobserved heterogeneity or not does not seem to axect the estimates of the ${ }^{-}{ }_{\mathrm{mn}}{ }^{\text {'s. }}$
} 
auditors. It resulted in a log likelihood of -1607.91 . Combining this with the log likelihoods of Table $9 \mathrm{~A}$ and $9 \mathrm{~B}$ results in a test statistic of 67.46 which exceeds the critical chi-squared value of 63.72 at the $5 \%$ signi..cance level. So the hypothesis of equal coec cients is rejected. Note that ${ }^{-}{ }_{m n}$ measures the marginal exect of $X_{m n}$ on $-\ln \left(\alpha_{0 m n}\left(T_{m n}\right)\right)$. The sign of the marginal exect of $X_{m n}$ on the duration $T_{m n}$ is contrary to the sign of ${ }^{-} \mathrm{mn}$ :

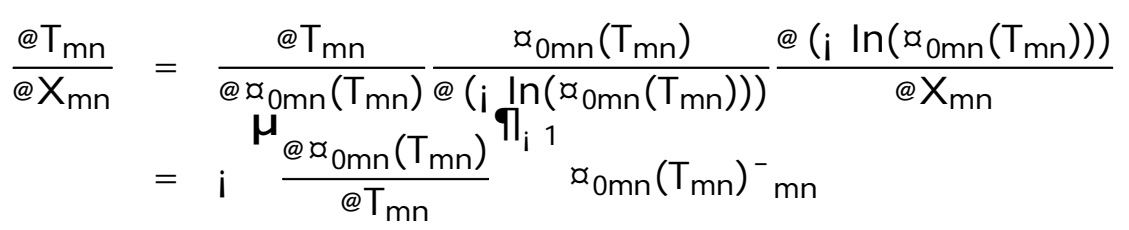

As Table 9 shows, for full-time educated auditors social background axects both $T_{p}$ and T, whereas for NIVRA educated auditors social background is not signi..cant. Full-time educated auditors whose father has completed higher education need signi..cantly less time to become partner and also leave the accounting ..rm signi..cantly faster. This combination. A possible explanation may be that the outside options are better for people from a higher social class which makes it easier for them to ..nd a proper job outside the accounting ..rm. ${ }^{13}$ The graduation year dummies suggest that auditors (from both educational types) who have recently graduated become partner sooner than people who have graduated some time ago. This ..nding is likely to occur because auditors who have graduated recently are still employed as non-partner and retain a chance of becoming partner. Graduation year does not axect $T_{l}$ : Auditors from NIvRA who have worked at another accounting ..rm have signi..cantly shorter durations until leaving the ..rm. Perhaps they do not like to work for any ..rm for a long time or perhaps they do not perform well at work. The exect is also present for the full-time educated auditors although it is not signi..cant there. Having worked for a dixerent accountancy ..rms (changed ..rm) has no exect on time to become partner, suggesting a quite open market. Relative study duration, de..ned as the time someone needed to complete the

\footnotetext{
${ }^{13} \mathrm{By}$ means of a Pearson $\hat{A}^{2}$ test we tested, using the current data-set, whether social background (measured by the respondent's mother educational level) axects outside options (measured by wage growth when changing employer). The corresponding test statistic is $\hat{A}^{2}(3)=5: 74$ indicating that there is an almost statistically signi..cant connection between the educational level of the mother and wage growth when changing employer. Given the relatively small data-set used, this supports the idea that social background axects someone's outside options. If we use father's education, the outside options are not signi..cantly better.
} 
accountancy divided by the average time auditors with the same accountancy training needed to complete this training, for NIvRA graduates decreases $T_{p}$ signi..cantly and increases $T_{\text {I }}$ signi..cantly. This is in contradiction to expectation. We took long relative duration as associated with being not very smart/or being ine屯 cient and consequently thought it would increase needed to become partner and decrease time until leaving. It is only present in the NIVRA estimation results. There may be a selection exect going on here. Assistant accountants who needed a long time to graduate but who also performed badly at work may have left the ..rm before graduating (and are therefore not included in the sample) whereas promising assistant accountants with a long relative study duration did not have to leave the accounting ..rms. This may also be the reason why the other ability indicator 'having done a re-exam at highschool' is not signi..cant. Gender also did not axect $T_{p}$ and $T_{l}$ : However, there are only a few percent women in the sample.

The estimates of the hazards represent the semiparametric baseline hazard function up to some factor of proportionality. ${ }^{14}$ The estimated hazards have multiple peaks, dixerent for the two destinations, but very similar for the two educations. According to the Hausman tests, equality of the baseline hazards can not be rejected for both destinations.

For both types of accountancy training the correlation between duration until partnership and duration until leaving the ..rm is not signi..cant, suggesting dixerent causes for leaving and becoming partner. For example, outside options may be important for those who leave but may not be related with becoming partner.

\footnotetext{
${ }^{14}$ In the proportional hazard model the hazard function is split up into a baseline hazard and a factor depending on individual characteristics and unknown parameters. $\operatorname{Exp}\left(\mathrm{X}_{\mathrm{mni}}{ }^{-}{ }_{\mathrm{mn}}\right)$ has not been scaled such that the baseline hazard corresponds with the baseline hazard for the mean value of the regressors.
} 
Table 9A : Up-or-out model, full-time education (dependent competing risks, semi-parametric, ML)

\begin{tabular}{|c|c|c|c|c|}
\hline & \multicolumn{2}{|c|}{$\bar{T} \bar{p}$} & \multicolumn{2}{|c|}{ 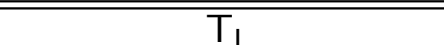 } \\
\hline variables & coec cient & $(s d)$ & coeç cient & $(s d)$ \\
\hline female & 0.278 & $(0.322)$ & 0.035 & $(0.694)$ \\
\hline father's education low & 0.211 & $(0.213)$ & 0.319 & $(0.278)$ \\
\hline father's education high & $0.458^{\infty}$ & $(0.206)$ & $0.502^{\alpha}$ & $(0.303)$ \\
\hline re-examination & 0.020 & (0.348) & -1.212 & (0.954) \\
\hline relative duration acc. ed. & -0.033 & $0.232)$ & 0.267 & $(0.323)$ \\
\hline get kids & $-0.910^{\infty}$ & $(0.184)$ & -0.442 & $(0.368)$ \\
\hline changed acc. ...rm & -0.230 & $(0.230)$ & 0.358 & $(0.329)$ \\
\hline graduated $1976-80$ & 0.260 & $(0.414)$ & 0.351 & $(0.362)$ \\
\hline graduated 1981-85 & 0.257 & $(0.375)$ & 0.202 & $(0.365)$ \\
\hline graduated $1986-90$ & 0.356 & $(0.321)$ & -0.180 & $(0.365)$ \\
\hline graduated 1991-95 & $1.234^{\infty}$ & $(0.322)$ & 0.473 & $(0.554)$ \\
\hline graduated 1996-98 & $1.421^{000}$ & $(0.506)$ & 1.535 & (1.079) \\
\hline \multicolumn{5}{|c|}{ parameters of the baseline hazard function } \\
\hline$(0.0-0.5]$ & - & - & $0.037 * 10^{i} 5$ & $\left(0.431 * 10^{i}{ }^{4}\right)$ \\
\hline$(0.5-1.0]$ & - & - & 0.018 & $(0.016)$ \\
\hline$(1.0-1.5]$ & - & - & 0.005 & $(0.007)$ \\
\hline$(1.5-2.0]$ & - & - & $0.044 * 10$ i 5 & $\left(0.537 * 10^{i}{ }^{4}\right)$ \\
\hline$(2.0-2.5]$ & - & - & 0.014 & $(0.016)$ \\
\hline$(2.5-3.0]$ & - & - & $0.048 * 10^{i} 5$ & $\left(0.622 * 10^{i} 4\right)$ \\
\hline$(3.0-3.5]$ & - & - & 0.009 & $(0.013)$ \\
\hline$(3.5-4.0]$ & - & - & 0.021 & $(0.026)$ \\
\hline$(4.0-4.5]$ & - & - & $0.106 * 10 ; 5$ & $\left(0.112 * 10^{i} 3\right)$ \\
\hline$(0.0-4.5]$ & $0.063^{\infty a x}$ & $(0.025)$ & - & - \\
\hline$(4.5-5.5]$ & $0.078^{\infty}$ & $(0.037)$ & 0.028 & $(0.032)$ \\
\hline$(5.5-6.5]$ & $0.164^{\infty}$ & $(0.073)$ & 0.042 & $(0.047)$ \\
\hline$(6.5-7.0]$ & $0.309 * 10^{i} 5$ & $\left(0.280 * 10{ }^{i}{ }^{3}\right)$ & - & - \\
\hline$(7.0-7.5]$ & 0.027 & $(0.029)$ & - & - \\
\hline$(7.5-8.0]$ & 0.087 & $(0.073)$ & - & - \\
\hline$(8.0-8.5]$ & 0.151 & $(0.112)$ & - & - \\
\hline$(8.5-9.0]$ & 0.070 & $(0.078)$ & - & - \\
\hline$(6.5-9.0]$ & - & - & 0.177 & $(0.149)$ \\
\hline$\left(9.0-\max T_{m}\right]$ & $0.151^{\alpha}$ & $(0.090)$ & 0.069 & $(0.052)$ \\
\hline $1 / 2$ & \multicolumn{2}{|c|}{0.346} & \multicolumn{2}{|c|}{$(0.611)$} \\
\hline $\log L$ & \multirow{2}{*}{\multicolumn{4}{|c|}{$\begin{array}{c}-664.38 \\
280\end{array}$}} \\
\hline $\mathrm{N}$ & & & & \\
\hline
\end{tabular}


Table 9B: Up-or-out model, NIvRA education (competing risks, semi-parametric, ML)

\begin{tabular}{|c|c|c|c|c|}
\hline & \multicolumn{2}{|c|}{$\bar{T} T_{p}$} & \multicolumn{2}{|c|}{$\overline{T_{1}}$} \\
\hline variables & coeç cient & $(\mathrm{sd})$ & coec cient & $(s d)$ \\
\hline female & -0.048 & $(0.541)$ & -0.345 & $(1.050)$ \\
\hline father's education low & 0.027 & $(0.188)$ & -0.327 & $(0.207)$ \\
\hline father's education high & -0.214 & $(0.315)$ & 0.109 & (0.299) \\
\hline re-examination & 0.078 & $(0.358)$ & -0.247 & $(0.427)$ \\
\hline relative duration acc. ed. & $0.576^{\alpha}$ & $(0.323)$ & $-0.644^{x}$ & $(0.363)$ \\
\hline get kids & $-0.538^{\infty x a}$ & $(0.215)$ & 0.345 & $(0.345)$ \\
\hline changed acc. ..rm & -0.243 & $(0.187)$ & $0.552^{\infty 00}$ & $(0.206)$ \\
\hline graduated $1976-80$ & 0.060 & $(0.332)$ & -0.124 & $(0.308)$ \\
\hline graduated 1981-85 & 0.201 & $(0.324)$ & 0.034 & $(0.311)$ \\
\hline graduated $1986-90$ & $0.549^{\alpha}$ & $(0.309)$ & 0.346 & (0.298) \\
\hline graduated 1991-95 & $0.765^{\infty \alpha}$ & $(0.332)$ & 0.059 & $(0.438)$ \\
\hline graduated 1996-98 & 0.026 & $(1.050)$ & -6.647 & (43.308) \\
\hline \multicolumn{5}{|c|}{ parameters of the baseline hazard function } \\
\hline$(0.0-0.5]$ & - & - & $0.288 * 10 \mathrm{i} 5$ & $\left(0.143^{*} 10^{i} 3\right)$ \\
\hline$(0.5-1.0]$ & - & - & 0.023 & $(0.017)$ \\
\hline$(1.0-1.5]$ & - & - & 0.040 & $(0.027)$ \\
\hline$(1.5-2.0]$ & - & - & 0.051 & $(0.034)$ \\
\hline$(2.0-2.5]$ & - & - & 0.009 & $(0.010)$ \\
\hline$(2.5-3.0]$ & - & - & 0.027 & $(0.021)$ \\
\hline$(3.0-3.5]$ & - & - & 0.019 & $(0.017)$ \\
\hline$(3.5-4.0]$ & - & - & 0.050 & $(0.035)$ \\
\hline$(4.0-4.5]$ & - & - & 0.011 & $(0.012)$ \\
\hline$(0.0-4.5]$ & $0.048^{\infty \alpha}$ & $(0.021)$ & - & - \\
\hline$(4.5-5.5]$ & $0.026^{\alpha}$ & $(0.015)$ & 0.076 & $(0.046)$ \\
\hline$(5.5-6.5]$ & $0.050^{\alpha}$ & $(0.027)$ & $0.153^{\alpha}$ & $(0.088)$ \\
\hline$(6.5-7.0]$ & 0.024 & $(0.021)$ & - & - \\
\hline$(7.0-7.5]$ & 0.080 & $(0.050)$ & - & - \\
\hline$(7.5-8.0]$ & 0.034 & $(0.029)$ & - & - \\
\hline$(8.0-8.5]$ & 0.054 & $(0.041)$ & - & - \\
\hline$(8.5-9.0]$ & 0.041 & $(0.036)$ & - & - \\
\hline$(6.5-9.0]$ & - & - & $0.225^{\alpha}$ & $(0.124)$ \\
\hline$\left(9.0-\max T_{m}\right]$ & $0.041^{\propto}$ & $(0.023)$ & $0.058^{\alpha}$ & $(0.034)$ \\
\hline $1 / 2$ & \multicolumn{2}{|c|}{0.016} & \multicolumn{2}{|c|}{$(0.346)$} \\
\hline $\log L$ & \multicolumn{4}{|c|}{-909.80} \\
\hline $\mathrm{N}$ & \multicolumn{4}{|c|}{336} \\
\hline \multicolumn{5}{|c|}{$*(* *)$ indicates signi...cance at the $10 \%(5 \%)$ level } \\
\hline
\end{tabular}

F igure 3 shows the estimated survivor functions based on the estimation results in table $9 \mathrm{~A}$ and 9B. The survivor functions do not dixer very much by education and the dixerences will not be statistically dixerent (cf. Hausman tests). The two upper graphs show the education 

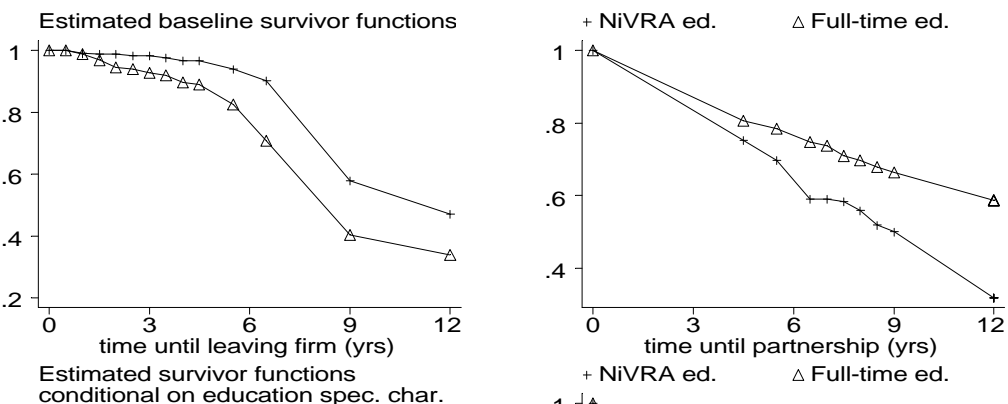
conditional on education spec. char.
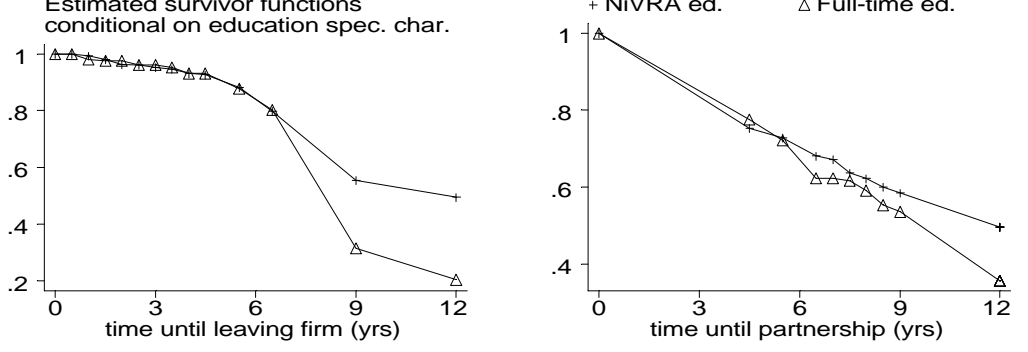

Figure 3: Estimated survivor functions

speci..c baseline survivor functions and the two lower graphs the survivor functions conditional on education and the average characteristics of leavers and partners. The estimated baseline survivor functions can be interpreted as the survivor function for an "average auditor", i.e. $\exp \left(\mathrm{X}_{\mathrm{mn}}{ }^{-} \mathrm{mn}\right)$ is ..xed at 1 whereas in the estimated survivor functions $\exp \left(\mathrm{X}_{\mathrm{mn}}{ }^{-} \mathrm{mn}\right)$ is calculated using the estimated values of ${ }^{-} \mathrm{mn}$ and the education speci..c average values of $X_{\mathrm{mn}}$ : The dixerence in exit rates increases over time. This suggests that the full-time and the parttime educated auditors do not dixer very much in getting promoted to middle management positions but that they may dixer in getting promoted to the higher management positions in the accounting ..rm.

The baseline survivor functions indicate that full-time educated auditors leave the ..rm relatively quickly, while an average NIVRA graduate becomes a partner relatively quickly. But recall the Hausman tests: the dixerences in baseline hazards are not signi..cant.

In the two lower graphs, the relatively low survivor function of the full-time educated auditors in case of leaving suggests that full-time educated auditors perform relatively badly in public auditing and have low chances of getting promoted to a higher job. However, it may also be that their outside options are better. Table 10 shows the relative wage growth in the ..rst new job after leaving the accounting ..rm for both educational types. A bout $40 \%$ 
of the auditors indicate that they earn substantially more in their new job (wage increase $>15 \%$ ). This indicates that not only the poorly performing auditors leave the ..rm but that there are also quite capable auditors who start working elsewhere. There is some mild evidence that the distribution of wage growth is not the same across the two educational types. A ccording to the Pearson's $\hat{A}^{2}$ test and the likelihood ratio-test ${ }^{15}$ the hypothesis of equal 'distributions' is rejected at the $10 \%$ level of signi..cance. The outside options for the full-time educated auditors are better than those of the NIvRA educated auditors. NIvRA educated auditors who leave have a three times higher probability of getting a wage decrease than full-time educated auditors who leave. Furthermore, among the auditors who get the highest wage increases there are relatively more full-time educated auditors than part-time educated auditors. This contradicts the view that the full-time educated auditors leave relatively often because they perform relatively badly and are losers in the tournament. It can be explained by the fact that they possess relatively more general human capital compared to the human capital of auditors educated by NIVRA.

Table 10

Relative wage increase in new job

\begin{tabular}{|c|c|c|c|c|}
\hline & \multicolumn{2}{|c|}{ full-time ed. } & \multicolumn{2}{|c|}{ NIvRA ed. } \\
\hline wage increase & \# & $(\%)$ & \# & (\%) \\
\hline$<0 \%$ & 4 & (3.1) & 14 & $(10.5)$ \\
\hline $0-5$ & 37 & $(28.5)$ & 32 & $(24.1)$ \\
\hline $6-15 \%$ & 36 & $(27.7)$ & 39 & (29.3) \\
\hline$>15 \%$ & 53 & $(40.8)$ & 48 & $(36.1)$ \\
\hline total & $\begin{array}{r}130 \\
\text { tes }\end{array}$ & $\begin{array}{l}\text { (100.1) } \\
\text { statistics }\end{array}$ & 133 & (100.0) \\
\hline Pearson's Â ${ }^{2}$ & 6.25 & & p-value $=$ & 0.100 \\
\hline likelihood ratio & 6.58 & & p-value $=$ & 0.087 \\
\hline
\end{tabular}

We may conclude that in the up-or-out world of public auditing, the baseline hazards for becoming a partner or leaving the ..rm are not statistically dixerent. But the relation with explanatory variables is not identical, even though the exects only manifest themselves after some six years of tenure. Remarkably, an exect of family background persists. Academic accountants with a higher educated father are quicker to become a partner, and have a lower

\footnotetext{
${ }^{15} \mathrm{~B}$ oth tests are done in Stata where they are standard tests. Pearson's $\hat{A}^{2}$ tests the null hypothesis that the rows and the columns in a two-way table are independent. The precise test statistics can be found in Stata reference manual release 6 (1999), vol. 4 p. 172-173.
} 
duration until leaving the ..rm. These exects are not present for NIvRA accountants. Higher exit rates from the ..rm, after six years, for academic accountants are consistent with the fact that they have slightly better outside options, as refected by higher wage growth in a new job. Again, this is consistent with a higher stock of general human capital for academic accountants.

\section{A n assessment}

Probably the most general conclusion we can draw is support for the hypothesis that the broader education at the university generates more general human capital and prepares for a broader career, with more substantial wage growth. Indeed, for employees we ..nd signi... cantly steeper wage pro..les for academic accountants than for NIVRA accountants, shorter tenures, higher job mobility, and greater earnings jumps when moving to another job, rełecting, presumably, better outside options for the accountants with the more general human capital. In the hazard functions for tenure with the ..rm, we ..nd signi..cant dixerences in the coec cients for experience before entering the ..rm, indicating that academic accountants respond with a stronger decline in expected tenure to a given increase in prior experience. This again points to more participation in job turnover, more active movement across the labor market.

In the up-or-out world of public accounting, we ..nd no dixerence in baseline hazards, some dixerence in the exect of explanatory characteristics, (leading to somewhat higher rates of leaving after some 6 years), no dixerence in survivor functions until partnership, and no dixerences in earnings among partners. So, it seems that among those accountants who remain active in public accounting, there is no dixerence in probability of making it to partnership (the hazard functions do not dixer signi..cantly), and once a partner, there is no dixerence in earnings.

In the education choice functions we have found substantial exects of family background, with having a higher educated father as a strong stimulus for the academic track. J ointly, these results suggest that the pool of talent in the two education systems is not dixerent (as measured by time to make it to a partnership in public auditing, and earnings once partner, in any ..rm), but that NIvRA was the route that provided students from low social backgrounds 
the opportunity to reach a position to match their abilities that students from more privileged backgrounds obtained through a university education. If so, there would be a strong cohort exect, and the need for a dual track for distributional reasons would be strongly diminished, as access to university is now no longer limited to privileged social backgrounds.

W ith our estimates we can make a crude comparison of lifetime incomes (Table 11). Needless to say that this comparison is conditioned by the extent and quality of the information we obtained, and should be interpreted cautiously. For a lifetime career as an employee, the academic education generates $6 \%$ higher net present value, at a discount rate of $5 \%$. There is barely a dixerence whether individuals are taken from the mean or the mode of their distributions $^{16}$. This is quite dixerent if we include individuals who make it to partner, either for sure $(P=1)$ or with probability $P$ as predicted ${ }^{17}$. For modal individuals, again the academic route has the highest rewards. But for average individuals, NIVRA now generates higher lifetime income. Still, the dixerences over a lifetime are quite small, reiterating our main conclusion.

\footnotetext{
${ }^{16} \mathrm{~F}$ or the modal auditor the values of the explanatory variables are ..xed on the modal values in the sample of employees. Modal values turned out to be the same for the two training types. The modal auditor who is employee has the following characteristics: he is married, works in the randstad (western cities), has a labor contract of 38 hours a week, receives emoluments and works for a large accounting ..rm. Combinations of tenure and work experience are according to educational type speci..c average combinations. The explanatory variables of the average auditor who is employee are ..xed at the education speci..c average values of audit employees. For employers the speci..cation of the average and the modal education speci..c employer runs analogously.

${ }^{17} \mathrm{~T}$ he transition to partner is assumed to be made at age 38 , in both cases.
} 
Table 11

Net present value of lifetime income $*(\neq .1000,-)$ at $r=0.05$

\begin{tabular}{|c|c|c|c|c|c|c|}
\hline \multirow[b]{3}{*}{ Full-time } & \multicolumn{2}{|c|}{$\begin{array}{l}\text { career path } 1 \\
\text { employee }\end{array}$} & \multicolumn{2}{|c|}{$\begin{array}{l}\text { career path } 2 \\
\text { partner } \mathrm{P}=1\end{array}$} & \multicolumn{2}{|c|}{$\begin{array}{l}\text { career path } 3 \\
\text { partner } P<1\end{array}$} \\
\hline & modal & average & modal & average & modal & average \\
\hline & 121.5 & 121.5 & 121.5 & 121.5 & 121.5 & 121.5 \\
\hline employee & $1,104.2$ & $1,111.1$ & 518.7 & 530.2 & 969.5 & 977.5 \\
\hline partner & 0 & 0 & $2,812.8$ & $2,442.2$ & 646.9 & 561.7 \\
\hline total & $1,225.7$ & $1,232.6$ & $3,453.0$ & $3,093.9$ & $1,737.9$ & $1,660.7$ \\
\hline NI vRA & & & & & & \\
\hline education & 169.4 & 169.4 & 169.4 & 169.4 & 169.4 & 169.4 \\
\hline employee & 978.7 & 995.3 & 599.3 & 613.6 & 876.3 & 892.2 \\
\hline partner & 0 & 0 & $2,487.5$ & $2,469.7$ & 671.6 & 666.8 \\
\hline total & $1,148.1$ & $1,164.7$ & $3,256.2$ & $3,252.7$ & $1,717.3$ & $1,728.4$ \\
\hline abs. dix. & 77.6 & 67.9 & 196.8 & -158.8 & 20.6 & -67.7 \\
\hline rel.diø. & $6.3 \%$ & $5.5 \%$ & $5.7 \%$ & $-5.1 \%$ & $1.2 \%$ & $-4.1 \%$ \\
\hline
\end{tabular}

Finally, let us brieły return to our speculation that dixerent educational tracks may dixerentiate graduates in three ways: by personality, by professional skill and by selection mechanisms. We have not been able to ..nd evidence of dixerences in personality. Stated motives for selecting a type of education indeed dixer, with students precisely claiming to appreciate each type's distinct features. Our experiments, not reported here, with direct observations on risk attitude (asking for their reservation prize for a speci..ed lottery ticket) and with time preference (asking for required compensation for postponing income) through simple survey questions, have failed. Unobservables played no dixerential role in earnings and tenure functions. We found clear support for predicted consequences of more general human capital emanating from the academic education, and this may associate with a personality dixerence, in the sense that certain types of individuals are especially attracted to the broader training and the wider career perspectives. Dixerences in selection mechanisms, or simply dixerent consequences of identical mechanisms, is something we remain uncertain about. It is quite plausible that among partners, earnings will not dixer by educational preparation, as both types presumably, go through the same ..Iter to become a partner. 


\section{References}

[1] Altonji, J.G. and R.A. Shakotko (1987), Do Wages Rise with J ob-Seniority?, Review of Economic Studies, 54, pp. 437-459.

[2] Han, A. and J. A. Hausman (1990), Flexible Parametric Estimation of Duration and Competing Risks Models, J ournal of Applied Econometrics 5, pp. 1-28.

[3] J onker, N. (2001), J ob Performance and Career Prospects of Auditors, Ph.D. Thesis, University of A msterdam.

[4] Imhox, E. van \& J J .M . Ritzen (1989), Comparing Employment Opportunities of Graduates and Drop-outs of Full-time Education and an in-service training program, Economics of Education Review 8, pp. 159-167.

[5] Lancaster, T. (1990), The E conometric A nalysis of Transition Data, Cambridge University Press, Cambridge.

[6] Lazear, E. P.(1995), Personnel Economics, MIT press, Massachuchetts.

[7] Lee, L. F. (1983), Generalized Econometric M odels with Selectivity, Econometrica 51, pp. 507-512.

[8] Nivra/Universiteit Nijenrode (1996), Universitaire deeltijd opleiding Accountancy studiegids 1996-1997, Nivra, A msterdam.

[9] Ophem, H. van and N. J onker (1997), The Duration of Higher Education: Semiparametric Estimation of a Dependent Competing Risks M odel, working paper, A msterdam.

[10] Plug, E.J.S. and W. Groot (1998), Apprenticeship versus Vocational Education: Exempli..ed by the Dutch situation, Working paper, A msterdam.

[11] Sollogoub, M. and V. Ulrich (1999), A pprenticeship versus Vocational school: Selectivity Bias and School to Work Transition, TSER working paper W P 09-99.

[12] Spurr, S. J . and G. T. Sueyoshi (1994), Turnover and Promotion of Lawyers. An Inquiry into Gender Dixerences, The J ournal of Human Resources 29, pp.813-842. 
[13] Stata (1999), Stata Preference Manual, release 6, vol. 4, pp. 172.

[14] Sueyoshi, G.T. (1992), Semiparametric proportional hazards estimation of competin g risks models with time-varying covariates, J ournal of E conometrics 51 (1-2), pp. 25-58.

[15] Teulings, C. and J. Hartog (1998), Corporatism or Competition? Labour Contracts, Institutions and Wage Stuctures in International Comparison, Cambridge, Cambridge University Press.

[16] Topel, R . (1991), Speci..c Capital, M obility, and Wages: Wages R ise with J ob Seniority?, J ournal of Political Economy, 99, pp. 994-1007.

[17] Vaatstra, R. (1996), Expertise in Accountancy. Empirisch onderzoek naar de kennisontwikkeling van student tot ervaren accountant, P hD-thesis, U niversitaire Pers M aastricht, Maastricht.

[18] Velden, R. van der and B. Lodder (1995), A Iternative R outes from Vocational E ducation to the Labour M arket. Labour M arket Exects of Full-time versus Dualized Vocational Education, Educational Research and Education 1, pp. 109-128. 


\section{Appendix A: Data}

The data are from a survey held among 3000 auditors in the Netherlands in the period December 1998-February 1999, drawn from the membership roll of the Royal NIVRA (of which every auditor is a member). The auditors in the sample are all working and aged 32-65 years. 1599 individuals have returned their questionaire. 1523 specify their education: 580 have university training, 717 have dual NIVRA training, 226 have a mixed training. The latter observations have not been used, as it would be too complicated to disentangle the relative contributions of the training types. The respondents represent the population very well. A ge, gender, type of accountancy education and work sector of the original sample and the respondents have been compared and there were no indications that the respondents dixer from the auditors in the sample. The survey registers individual characteristics, job characteristics and work histories.

The samples are characterized in Table A 1 . We distinguish employees and employers/ partners. Employers operate their own independent business ..rms, partners have been invited to become partner in an accountancy ..rm operated as a partnership. For employees, composition by sector of work dixers markedly, with academic accountants working more often in the ..nancial-administrative sector, and less frequently in the public sector. NIvRA accountants more often are from a lower social background, with a lower educated father. They failed less often for their secondary school exam, although the dixerence is statistically not signi..cant. A mong partners of accountancy ..rms, again NIVRA accountants have more often a father with a low education. They work more often in public accounting and in their schooldays they lived farther away from a university. 
Table A 1 Variables: means and standard deviations Employees

\begin{tabular}{lllll}
\hline \hline & & & & \\
& \multicolumn{2}{c}{ NIvR A } & education & \multicolumn{2}{c}{ full-time education } \\
wage interval & 4.279 & $(1.063)$ & 4.179 & $(1.207)$ \\
married & 0.930 & $(0.256)$ & 0.891 & $(0.312)$ \\
tenure/ 10 & 1.263 & $(0.994)$ & 0.791 & $(0.705)$ \\
randstad & 0.540 & $(0.499)$ & 0.616 & $(0.487)$ \\
expr/ 10 & 2.416 & $(0.722)$ & 1.497 & $(0.728)$ \\
expr ${ }^{2}=100$ & 6.355 & $(3.627)$ & 2.769 & $(2.920)$ \\
In(hours/ 10) & 1.332 & $(0.116)$ & 1.353 & $(0.068)$ \\
emoluments & 0.465 & $(0.499)$ & 0.543 & $(0.499)$ \\
..rm size 2-100 & 0.129 & $(0.336)$ & 0.115 & $(0.319)$ \\
..rm size 101-1000 & 0.366 & $(0.482)$ & 0.325 & $(0.469)$ \\
public auditing & 0.246 & $(0.431)$ & 0.238 & $(0.427)$ \\
internal auditing & 0.112 & $(0.316)$ & 0.081 & $(0.274)$ \\
..n. adm. sector & 0.344 & $(0.476)$ & 0.465 & $(0.500)$ \\
public sector & 0.165 & $(0.371)$ & 0.106 & $(0.309)$ \\
non auditing job & 0.133 & $(0.341)$ & 0.109 & $(0.312)$ \\
in publ. sector & & & & \\
$>$ >10 km. univ. & 0.796 & $(0.403)$ & 0.745 & $(0.436)$ \\
ed. father low & 0.496 & $(0.501)$ & 0.305 & $(0.461)$ \\
ed. fath. high & 0.134 & $(0.341)$ & 0.294 & $(0.294)$ \\
re-examination & 0.055 & $(0.228)$ & 0.070 & $(0.256)$ \\
start study late & 0.263 & $(0.441)$ & 0.227 & $(0.419)$ \\
$\mathrm{N}$ & 456 & & 357 & \\
\hline \hline
\end{tabular}


Table A 1

Employers/ partners

NIVRA ed. full-time ed.

\begin{tabular}{lllll} 
wage interval (1-8) & 6.098 & $(2.022)$ & 5.890 & $(1.822)$ \\
pro..t interval (1-9) & 5.942 & $(2.443)$ & 6.095 & $(2.121)$ \\
tenure/ 10 & 1.704 & $(1.079)$ & 1.435 & $(0.868)$ \\
randstad & 0.506 & $(0.502)$ & 0.539 & $(0.502)$ \\
experience/ 10 & 2.755 & $(0.656)$ & 2.075 & $(0.750)$ \\
In(hours/ 10) & 1.641 & $(0.202)$ & 1.637 & $(0.243)$ \\
..rm size 2-10 & 0.171 & $(0.378)$ & 0.171 & $(0.379)$ \\
..rm size 11-100 & 0.316 & $(0.467)$ & 0.197 & $(0.401)$ \\
..rm size 101-1000 & 0.095 & $(0.294)$ & 0.184 & $(0.390$ \\
public acc. & 0.924 & $(0.266)$ & 0.816 & $(0.390)$ \\
$>10$ km univ. & 0.791 & $(0.408)$ & 0.618 & $(0.489)$ \\
ed. father low & 0.525 & $(0.501)$ & 0.329 & $(0.473)$ \\
ed. father high & 0.158 & $(0.366)$ & 0.316 & $(0.468)$ \\
re-examination & 0.057 & $(0.233)$ & 0.039 & $(0.196)$ \\
start study late & 0.215 & $(0.412)$ & 0.184 & $(0.390)$ \\
N & 158 & & 76 & \\
\hline \hline
\end{tabular}

Gross income was measured in intervals. For employers two sources of income have been distinguished, namely ..xed gross monthly salary and pro..ts in 1997. M ost partners have these two sources of income. Only $20 \%$ of the partners (of both educational types) just receive pro..t.

In Tables A 2 and A 3 the distributions of employees' and partners' wages by accountancy training are shown. Table $A 2$ shows that only a few auditors have a monthly wage of $D \neq .6000$ or less. Therefore, the categories with wage $<=$ $D \ddagger 6000$ are lumped together in the estimations. Furthermore, there does not seem to be much dixerence in wages between the two types of auditors. In the wage category $D \ddagger 6001-D \ddagger 7500$ there are relatively many full-time educated 
auditors whereas in wage category $D \ddagger$. 9001- $D \ddagger 12000$ there are relatively many part-time educated auditors.

In Table A 3 two income components of partners are distinguished, i.e. gross ..xed monthly salary and pro..t after subtracting running costs. Full-time educated partners seem to have a higher monthly wage than part-time educated partners: there are relatively few full-time educated auditors with monthly wages between $D \ddagger 9001-12000$ and there are relatively many full-time educated auditors in the two highest wage categories. For the second income source, profits, full-time educated auditors seem to be relatively often in the lowest and the highest pro..t category.

Table A 2

Gross wage categories of employees by accountancy training

\begin{tabular}{llllll}
\hline \hline & \multicolumn{5}{c}{ Accountancy training } \\
Monthly wage 1998 (in Df.) & NIvRA & \multicolumn{5}{c}{ full-time } \\
& number & $\%$ & number & $\%$ & total \\
& 0 & 0 & 0 & 0 & \\
\hline $0-2500$ & 0 & 0 & 3 & 0.66 & 3 \\
$2501-3500$ & 2 & 0.39 & 1 & 0.22 & 3 \\
$3501-4500$ & 5 & 0.98 & 5 & 1.10 & 10 \\
$4501-6000$ & 19 & 3.74 & 37 & 8.17 & 56 \\
$6001-7500$ & 87 & 17.13 & 82 & 18.10 & 169 \\
$7501-9000$ & 224 & 44.09 & 172 & 37.97 & 396 \\
$9001-12000$ & 80 & 15.75 & 70 & 15.45 & 150 \\
$12001-15000$ & 91 & 17.91 & 83 & 18.32 & 174 \\
$>15000$ & 508 & 100.00 & 453 & 100.00 & 961 \\
\hline Total & 209 & & 127 & & \\
\hline \hline Income missing & & & & & \\
& & & & &
\end{tabular}


Table A 3

Income sources of partners

Accountancy training

\begin{tabular}{llllll} 
monthly wage $1998(\mathrm{D} \ddagger)$ & NIvRA & \multicolumn{5}{l}{ full-time } \\
\hline & number & $\%$ & number & $\%$ & total $^{1}$ \\
$1-3500$ & 3 & 1.94 & 4 & 4.94 & 7 \\
$3501-4500$ & 0 & 0 & 0 & 0 & 0 \\
$4501-6000$ & 2 & 1.29 & 3 & 3.70 & 5 \\
$6001-7500$ & 3 & 1.94 & 2 & 2.47 & 5 \\
$7501-8000$ & 6 & 3.87 & 4 & 4.94 & 10 \\
$9001-12000$ & 25 & 16.13 & 9 & 11.11 & 34 \\
$12001-15000$ & 24 & 15.48 & 12 & 14.82 & 36 \\
$15001-20000$ & 26 & 16.77 & 9 & 11.11 & 35 \\
$20001-25000$ & 11 & 7.10 & 9 & 11.11 & 20 \\
$>25000$ & 43 & 27.74 & 29 & 35.80 & 72 \\
\hline Total & 155 & 100 & 88 & 100 & 224 \\
Income missing & 31 & & 20 & & 51
\end{tabular}

pro..t

excl ..xed salary) 1997

\begin{tabular}{llllll}
\hline $1-49999$ & 5 & 3.07 & 9 & 10.11 & 14 \\
$50000-99999$ & 10 & 6.13 & 4 & 4.49 & 14 \\
$100000-149999$ & 12 & 7.36 & 7 & 7.87 & 19 \\
$150000-199999$ & 18 & 11.04 & 8 & 8.99 & 26 \\
$200000-249999$ & 13 & 7.98 & 8 & 8.99 & 21 \\
$250000-299999$ & 17 & 10.43 & 8 & 8.99 & 25 \\
$300000-499999$ & 43 & 26.38 & 19 & 21.35 & 62 \\
$500000-699999$ & 31 & 19.02 & 15 & 16.85 & 46 \\
$>700000$ & 14 & 8.59 & 11 & 12.36 & 25 \\
\hline total & 163 & 100.00 & 89 & 100.00 & 252 \\
pro..t missing & 9 & & 11 & & 20 \\
\hline \hline
\end{tabular}


Figure 1 shows the empirical distribution of the tenure durations of the dixerently educated auditors. The two upper graphs refer to completed tenures and the two lower graphs refer to uncompleted (censored) tenures. The two upper graphs show that only a small fraction of the people have a tenure of three years or less or a tenure larger than 10 (full-time education) or 15 (parttime education) years. The two lower graphs show that most uncensored tenures lie between 9 and 15, but still a substantial proportion of the censored tenures lie beyond 15 years. This is especially true for the part-time educated auditors ${ }^{2}$. The average uncensored tenures of part-time educated auditors is 10.1 years (standard deviation 6.1 years) which is much higher than the average uncensored tenures of full-time educated auditors which is 7.0 years (standard deviation 4.5 years).

In Figure 2 the $\mathrm{K}$ aplan-M eier estimates of the survivor function of tenure for both educational types is shown. There, we see that the survivor functions become steeper during the ..rst years of tenure, straighten for some stretch and then $\ddagger$ atten out. In terms of hazard rates, the pro..le of the hazard rate seems to be increasing and reaches its top somewhere between 5-8 years. After that point the hazard rate decreases.

As we also analyze the duration until promotion to partnership or until leaving the accounting ..rm, we will brieły characterize the data here. This analysis is restricted to auditors whose ..rst job after graduating as an auditor was in public accounting, as in this sector only the up-or-out contract is a standard feature. The starting date is graduation as a fully quali..ed auditor, i.e one has completed the post-doctoral university education in auditing or has completed

\footnotetext{
${ }^{1} \mathrm{~T}$ he totals of ..xed monthly wage and pro..t after subtracting running costs do not add up to 323 since most employers/ partners both receive a ..xed monthly salary and pro..t after substracting running costs.

${ }^{2} \mathrm{~T}$ he lower bound of 9 years refers to people who have just started working at their 1990 employer in J anuary 1990 and who are still employed in December 1998, the month the survey was taken.
} 

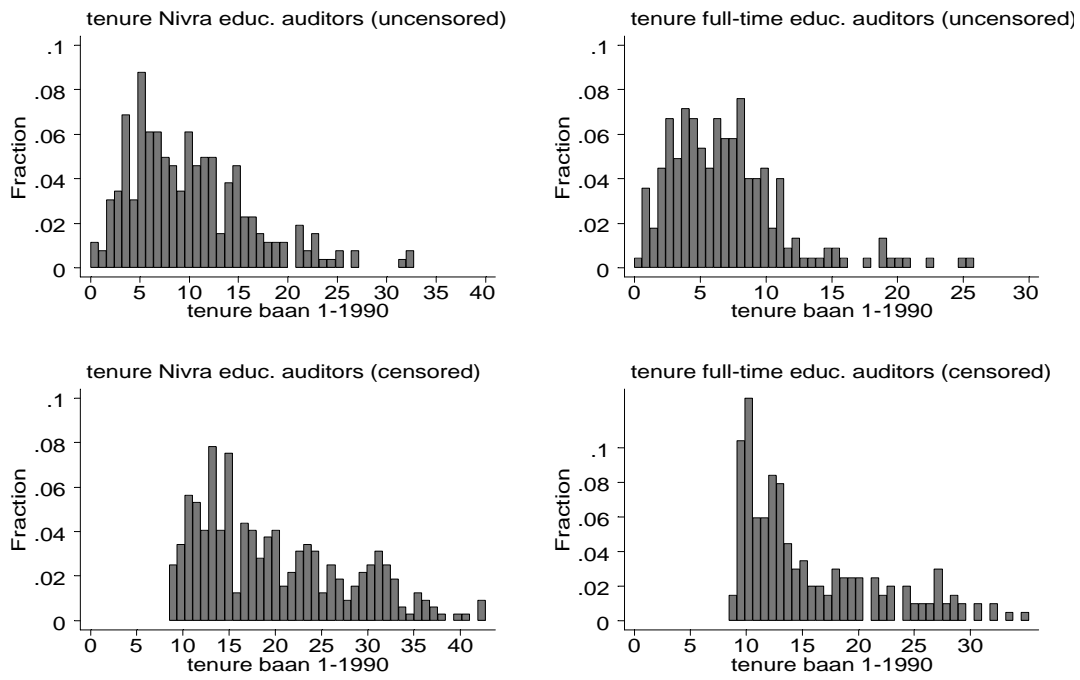

Figure 1: Distribution of observed tenure by education

Kaplan-Meier survival estimates, by fulltime

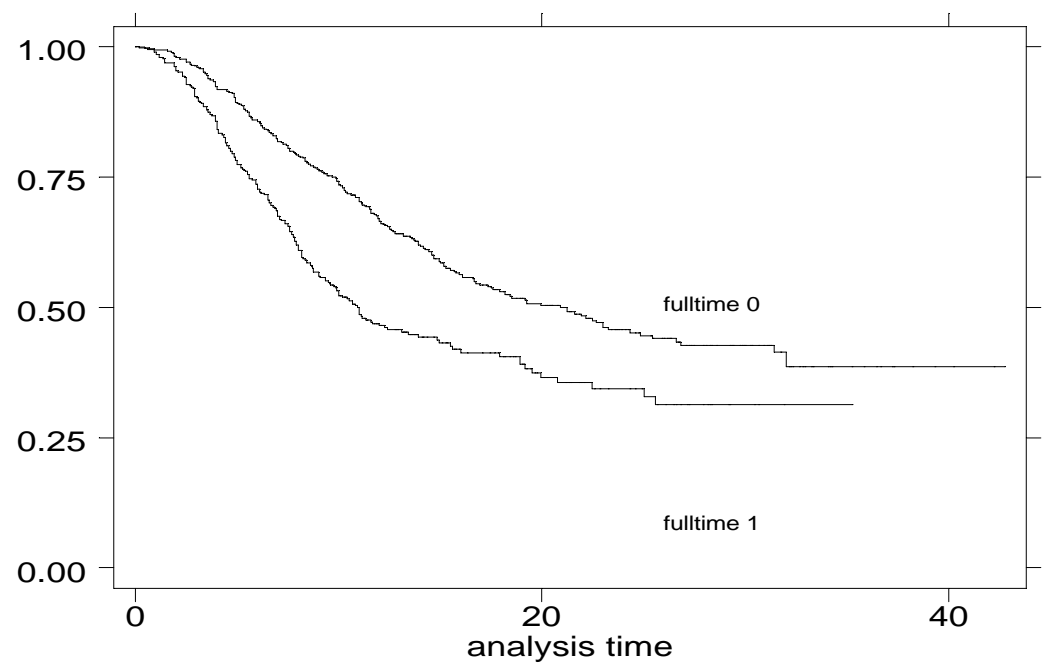

Figure 2: Kaplan Meier survival estimates of tenure 
the part-time N IVRA training in auditing. Unfortunately, only the year of graduating is known and not the month. It is assumed that people graduate in the middle of the year. W ith this choice the maximum error in graduating month is minimized to half a year. The end date is the month in which the auditors become partner or leave the accounting ..rm. Of the 1599 auditors in the sample 826 were working in public auditing when they graduated. 616 observations were retained, after deleting observations with missing information on essential variables. Of these 616 observations 280 observations have a full-time education in auditing and 336 observations have the NIVRA education.

Table A 4 presents some summary statistics on type of exit and duration until exit for each education. Full-time educated auditors appear less likely to become partner than the NIVRA educated auditors. The average duration until partnership is lower for the NIVRA educated auditors ( 6.3 years vs. 7.3 years). In addition full-time educated auditors leave the accounting ..rm more often and, on average, it takes them less time to do so (4 years against 4.7 years). A bout a quarter of the sample was still working as non-partner at the accounting ..rm. The average right-hand censored duration of NIvRA educated auditors is 2.4 years higher than that of their full-time educated counterparts.

Table A 4

Descriptive statistics duration (years)

\begin{tabular}{|c|c|c|c|c|c|c|}
\hline & type of exit & $\%$ & mean & $\mathrm{sd}$ & $\min$ & $\max$ \\
\hline \multirow[t]{3}{*}{ full-time ed. } & partner & 25.0 & 6.33 & 3.29 & 0.54 & 21.54 \\
\hline & left ..rm & 49.3 & 4.69 & 4.46 & 0.13 & 20.46 \\
\hline & still working & 25.7 & 9.88 & 6.83 & 0.46 & 30.36 \\
\hline \multirow[t]{3}{*}{ NIvRA ed. } & partner & 35.1 & 7.29 & 3.07 & 0.54 & 15.54 \\
\hline & left ...rm & 42.0 & 4.03 & 3.37 & 0.13 & 18.96 \\
\hline & still working & 22.9 & 7.46 & 6.15 & 0.46 & 28.45 \\
\hline
\end{tabular}



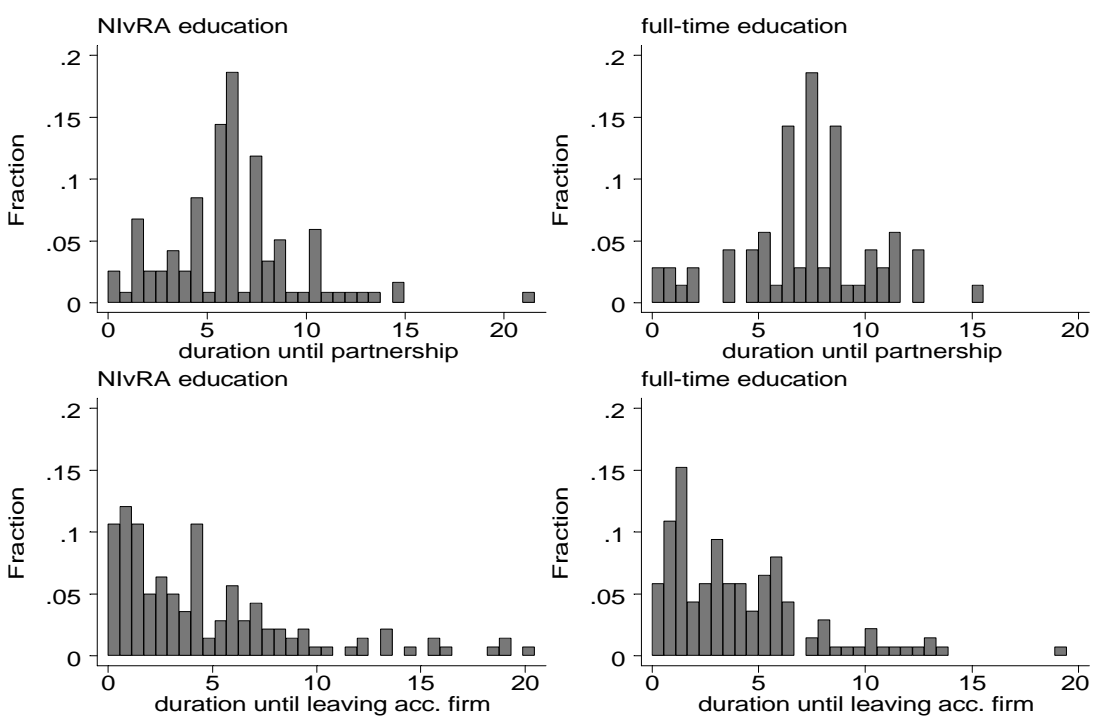

Figure 3: Frequency distributions of time until partnership and time until leaving the ..rm

Figure 3 gives the empirical distributions of the duration until partnership or leaving the ..rm for each education. The two upper graphs show the empirical distribution of duration in case of leaving the accounting ..rm. During the ..rst ..ve years after graduating there are not many auditors who become partner. $M$ ost auditors who become partner do so some $5-10$ years after graduating. Table A5 shows in which months auditors become partner or leave the accounting ..rm. Most partners (about two-thirds) start partnership in J anuary. This causes multiple peaks in the empirical distribution until partnership and in the corresponding hazard functions. This can also be seen in Figure 3, especially for full-time education where three peaks can be distinguished corresponding with the ..rst half of the year. Leaving the ..rm occurs throughout the year but is higher in the second half of the year than in the ..rst half of the year. This is more clearly seen in Table A5 than in Figure 3. 
Table A 5

\begin{tabular}{|c|c|c|}
\hline & partnership & leaving \\
\hline J anuary & 127 & 13 \\
\hline February & 3 & 19 \\
\hline March & 4 & 21 \\
\hline April & 5 & 16 \\
\hline May & 5 & 17 \\
\hline J une & 3 & 16 \\
\hline J uly & 3 & 19 \\
\hline August & 5 & 40 \\
\hline September & 9 & 29 \\
\hline October & 6 & 25 \\
\hline November & 2 & 12 \\
\hline December & 9 & 47 \\
\hline unknown ${ }^{3}$ & 7 & 5 \\
\hline total & 188 & 279 \\
\hline
\end{tabular}

Figure 4 shows education speci..c K aplan-M eier survival estimates for both exits. The vertical axes show the percentage employees who still have not become partner, respectively left the ..rm after a particular number of years working as a quali..ed auditor at an accounting ..rm. The survivor functions come quite close at $\S 8$ and 10 years and cross at 11 years. Until about 11 years the survivor function of the NIVRA educated auditors lies below the survivor function of the full-time educated auditors and then lies above it. The log-rank test and the Wilcoxon (Breslow) test for equality of survivor functions have been performed. The log rank test is most appropriate when the hazard functions are thought to be proportional across the groups if they are not equal and the Wilcoxon (B reslow) test is appropriate when the hazard functions are thought to vary in

\footnotetext{
${ }^{3}$ A uditors whose months are unknown are not deleted from the sample. It is assumed that they became auditor or left the ..rm in the middle of the year.
} 

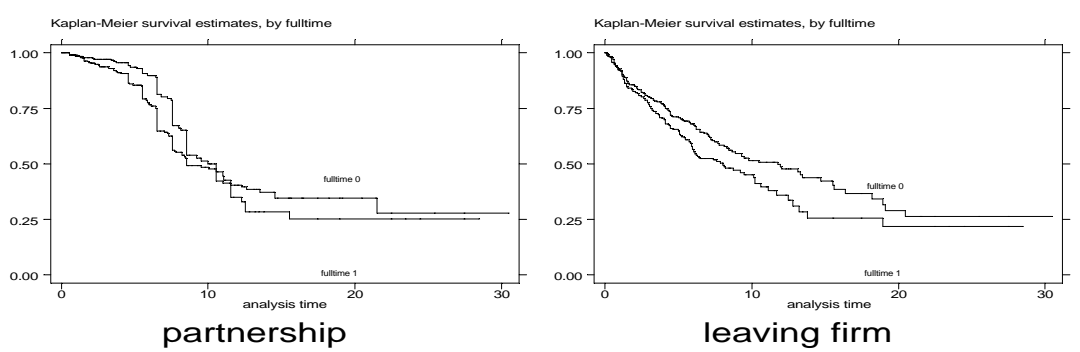

Figure 4: Kaplan M eier estimates of the survivor functions

other ways than proportionality if they are not equal. The W ilcoxon (B reslow) test rejects the hypothesis of equal survival functions(destination partnership) at the $1 \%$ level of signi..cance but the log rank test does not even reject it at the $10 \%$ level of signi..cance. However, since the hazard functions are clearly not proportional to each other (they cross) the W ilcoxon test seems to be most appropriate for this situation. The right graph shows the survivor functions until leaving the ..rm. The survivor function of the full-time educated auditors lies below the survivor function of the NIvR A educated auditors. The dixerence between the two survivor functions increases over time. According to both the log-rank test and the Wilcoxon (Breslow) test the two survivor functions are not equal at the $5 \%$ level of signi..cance. 


\section{A ppendix B: Econometric model wages}

A bivariate ordered probit model is used to analyze educational choice and income simultaneously. In order to allow for endogeneity in accountancy training ${ }^{4}$, income and educational type are jointly modelled, full-time education (subscript f) and part-time education (subscript $p$ ). There is a latent educational choice variable $I_{1 \mathrm{i}}^{\mathrm{x}}$ and an observed choice variable $I_{1 \mathrm{i}}: I_{1 \mathrm{i}}$ equals one in case of parttime education and equals zero in case of full-time education. The variables explaining educational choice for individual $i$ are stored in vector $Z_{i}$ :

$$
\begin{aligned}
& I_{1 i}^{\infty}={ }^{\circ} Z_{i} i \quad u_{i} \\
& \operatorname{Pr}\left(I_{1 i}\right.=1)() \quad u_{i}<={ }^{\circ} Z_{i} \\
& \operatorname{Pr}\left(I_{1 i}=0\right) \quad() \quad u_{i}>{ }^{\circ} Z_{i}
\end{aligned}
$$

It is assumed that $u_{i}$ has a standard normal distribution with mean zero and variance 1.

Vector $\mathrm{X}_{\mathrm{i}}$ stores the explanatory variables of wage. For each educational regime a log linear wage equation is speci..ed:

$$
\begin{aligned}
& \ln \left(y_{p i}^{\alpha}\right)={ }_{p}^{-} x_{i}+{ }_{p i} \\
& \ln \left(y_{f i}^{\alpha}\right)={ }_{f} x_{i}+{ }_{f i}
\end{aligned}
$$

with " $\mathrm{ji}$ having a normal distribution with mean zero and variance $3 / 2 / \mathrm{j} ; \mathrm{j}=\mathrm{p}$, f. Actual monthly wage $y_{j i}^{\mathfrak{a}}$ is not observed. Instead an ordered variable $y_{j i}$ is observed which indicates within which interval actual income $y_{j i}^{a}$ lies. The upper and lower bound of the income categories are known. For the employees,

\footnotetext{
${ }^{4}$ It may be argued that other explanatory variables like sector or being employee, partner or self-employed auditor are also endogenous. However, there is not enough information in the data-set which could explain these variables and the econometric model would become much more complicated. Therefore, this paper only deals with possible endogeneity in educational choice.
} 
six income categories are distinguished ${ }^{56}$ :

$$
\begin{aligned}
& \mathrm{y}_{\mathrm{ji}}=0 \quad() \quad \mathrm{y}_{\mathrm{ji}}^{\mathrm{d}}<=\mathrm{D} \neq .6 .000,- \\
& \mathrm{y}_{\mathrm{ji}}=1 \text { ( ) Dł. } 6.000<\mathrm{y}_{\mathrm{ji}}^{\mathrm{a}}<=\mathrm{D \neq} \text {. 7.500,- } \\
& y_{j i}=2() \quad \text { Dł. } 7.500<y_{j i}^{\alpha}<=D \neq .9 .000 \text {,- } \\
& \mathrm{y}_{\mathrm{ji}}=3\left(\text { ) D } \quad \text { ‡. } 9.000<\mathrm{y}_{\mathrm{ji}}^{\mathrm{a}}<=\mathrm{D} \neq .12 .000\right. \text {,- } \\
& \mathrm{y}_{\mathrm{ji}}=4() \quad \mathrm{D} \neq .12 .000<\mathrm{y}_{\mathrm{ji}}^{\mathrm{\alpha}}<=\mathrm{D} \neq .15 .000 \text {,- } \\
& y_{j i}=5() \quad y_{j i}^{a}>D \ddagger .15 .000,-
\end{aligned}
$$

Using equations 1 and 2 and denoting the correlation between $\mathrm{u}_{\mathrm{i}}$ and $\mathrm{j}_{\mathrm{i}}$ by $1 / j_{i} j=p, f$, the econometric model of the joint distribution of educational choice and income is speci..ed as follows:

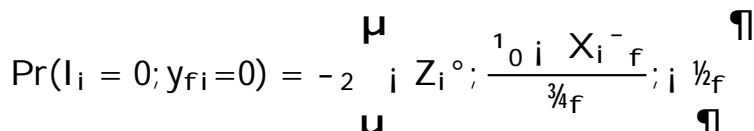

$$
\begin{aligned}
& \operatorname{Pr}\left(\mathrm{I}_{\mathrm{i}}=1 ; \mathrm{y}_{\mathrm{pi}}=0\right)=-2 \mathrm{Z}_{\mathrm{i}}{ }^{0} ; \mathrm{i} \frac{{ }^{1}{ }_{0} \mathrm{i} \mathrm{X}_{\mathrm{i}}{ }^{-} \mathrm{p}}{3 / \mathrm{p}} ;{ }^{1 / \beta}
\end{aligned}
$$

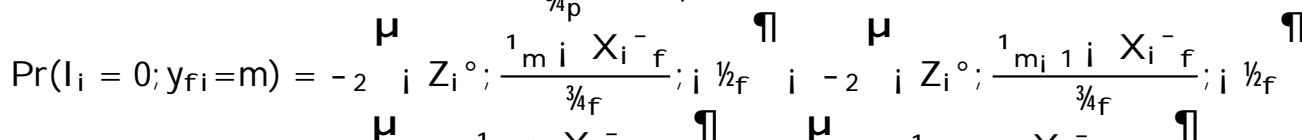

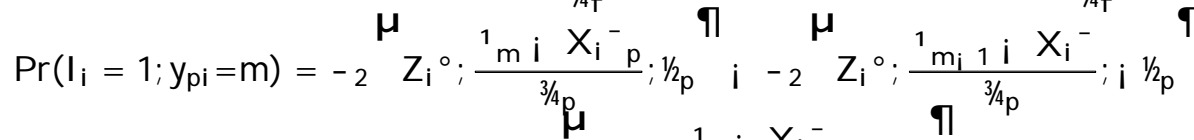

$$
\begin{aligned}
& \operatorname{Pr}\left(I_{i}=0 ; y_{f} i=5\right)=-{ }_{1}\left(i Z_{i}{ }^{\circ}\right) i-2 \quad i Z_{i}{ }^{0} ; \frac{{ }^{1} 4 i X_{i}{ }^{-} f}{3 / 4} ; i \frac{1 / p}{9} \\
& \operatorname{Pr}\left(I_{i}=1 ; y_{p i}=5\right)=-{ }_{1}\left(Z_{i}{ }^{\circ}\right) i-2^{\mu} Z_{i}{ }^{\circ} ; \frac{1{ }_{4} i X_{i}{ }^{-}}{3 / \beta} ; i^{1 / \beta}
\end{aligned}
$$

for $1<=m<=4$ and -2 denoting the bivariate normal distribution function and - denoting the univariate normal distribution function. Now, the log like-

\footnotetext{
${ }^{5} \mathrm{~T}$ he derivation of the joint probability distribution of education and income or education and trading pro..ts of employers/ partners runs analogously.

${ }^{6} \mathrm{~T}$ he three lowest wage categories and the two lowest pro..t categories of partners have also been lumped together in the estimations.
} 
lihood function can be derived:

$$
\begin{gathered}
\log L={ }_{i=1}^{X n} I_{i}{ }^{i} \operatorname{Pr}\left(I_{i}=0 ; y_{f i}=0\right)^{y_{f i}=0}+\ldots . .:+\operatorname{Pr}\left(I_{i}=0 ; y_{f i}=5\right)^{y_{f i}=5}+ \\
\left(1 ; I_{i}\right){ }^{i} \operatorname{Pr}\left(I_{i}=1 ; y_{p i}=0\right)^{y_{p i}=0}+\ldots: .+\operatorname{Pr}\left(I_{i}=1 ; y_{p i}=5\right)^{y_{p i}=5}{ }^{\$}
\end{gathered}
$$




\section{A ppendix C: Econometric model tenure}

Suppose that there are two types of accountancy training, $p$ (part-time) and $f$ (full-time). Individuals who want to become auditor are not randomly assigned to these two forms of education but they choose which education they want to have. Let $\mathrm{I}_{1 \mathrm{i}}^{\mathrm{x}}$ be the latent educational choice variable and $\mathrm{Z}_{\mathrm{i}}$ be the vector of exogenous variables determining educational choice:

$$
\mathrm{I}_{1 \mathrm{i}}^{\mathrm{x}}={ }^{\circ} \mathrm{Z}_{\mathrm{i}}+{ }_{\mathrm{i}}
$$

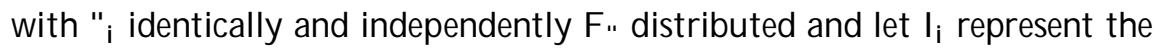
observed educational choice. $I_{1 i}=1$ if individual $i$ has part-time education and $I_{1 i}=0$ if individual $\mathrm{i}$ has chosen full-time education:

$$
\begin{aligned}
& I_{1 i}=\left.1 i \not\right|_{1 i} ^{\alpha}>0 \\
& I_{1 i}=\left.0 i \not\right|_{1 i} ^{\alpha}<=0
\end{aligned}
$$

We want to derive the joint probability function of type of treatment $I_{1 i}$ and the duration of tenure. We assume that each education has its own cumulative distribution function $F_{j}$ of $T_{j}$ with $j=p$ or $f$. If education axects tenure then this is refected by dixerences between the distribution functions $F_{p}$ and $F_{f}$.

$$
T_{p} \sim F_{p}\left(T_{p}\right) \text { and } T_{f} \sim F_{f}\left(T_{f}\right)
$$

The joint distribution function of educational type and tenure can be obtained by employing the method suggested by Lee (1983). Lee proposes a method to transform two continuous random variables with known marginal distributions into a bivariate distribution in which the random variables are allowed to correlate. This transformation is very useful if one needs the joint distribution function of two random variables from dixerent families. By transforming these marginal distribution functions to the standard normal distribution the joint distribution function of the two transformed random variables is the standard bivariate distribution function. The standard bivariate distribution function is easy to deal with in the estimations of the model in contrast 
to the joint distribution of the original marginal distribution functions which is unestimable ${ }^{7}$. Starting from assumptions 2.1 and 2.2 and denoting the correlation between $T_{p}$ and " by $1 / 2$ and the correlation between $T_{f}$ and " by $1 / 2 f$, we de.ne:

$$
\begin{aligned}
& i_{p}=J_{p}\left(T_{p}\right)=\odot{ }^{i}{ }^{1}\left(F_{p}\left(T_{p}\right)\right) \\
& \Sigma_{f}=J_{f}\left(T_{f}\right)=C^{i}{ }^{1}\left(F_{f}\left(T_{f}\right)\right) \\
& \iota^{\prime \prime}=J "(")=\text { () }{ }^{i}\left(F_{n}(")\right)
\end{aligned}
$$

where (i ${ }^{1}(:)$ is the inverse of the standard cumulative normal distribution function. The transformed variables $i p ; i$ if and $i$ " are standard normal random variables irrespective of the distributions of the original durations. The bivariate

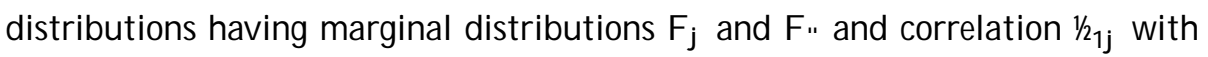
$j=p, f$ are given by:

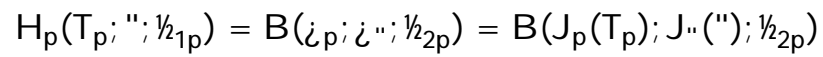

$$
\begin{aligned}
& H_{f}\left(T_{f} ; " ; 1 / z f f\right)=B(i f ; i n ; 1 / z f f)=B\left(J_{f}\left(T_{f}\right) ; J "(") ; 1 / z f f\right)
\end{aligned}
$$

where $B\left(., .1 \frac{1}{z_{j}}\right)$ is the bivariate normal distribution with zero means, unit variances and correlation $1 / z_{\mathrm{j}}$ : N ote that through the transformation to normality of the original marginal distribution functions the correlation of the original distributions $H_{p}$ and $H_{f}$ is not the same as the correlation of the standard bivariate normal distribution of the transformed durations. The corresponding

\footnotetext{
${ }^{7}$ Van O phem and J onker (1997) have used Lee's method when analyzing study duration in higher education. There, they used a semi-parametric dependent competing risks model. Van O phem (1999) shows that Lee's transformation method is not restricted to deriving the joint distribution function of two continuous random variables but can be extended to deriving the joint distribution function of any combination of continuous and discrete random variables.
} 
bivariate density functions equal:

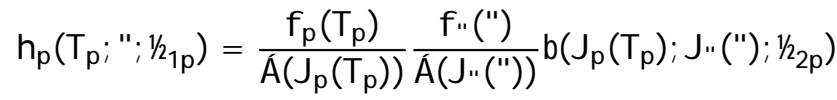

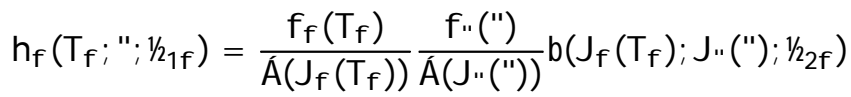

where $f_{p} ; f_{f}$ and $f_{\text {" }}$ are the marginal density functions of $T_{p} ; T_{f}$ and " and $b\left(.,: i^{1} / z_{j}\right)$ is the bivariate standard normal density function of $\left(i_{j} ; "\right)$ with $j=p$, f.

Due to the possibility of right-censored tenures there are four groups of individuals to distinguish:

1. individuals with part-time education and observed tenures: $T_{p}=t_{i}$ and ${ }^{i}>_{i}{ }^{\circ} Z_{i}$

2. individuals with full-time education and observed tenures: $T_{f}=t_{i}$ and ${ }_{i}$ $<=\mathrm{i}^{\circ} \mathrm{Z}_{\mathrm{i}}$

3. individuals with part-time education and right-censored tenures after $t_{c}$ years: $T_{p}>t_{c}$ and ${ }^{{ }_{i}}>_{i}{ }^{\circ} Z_{i}$

4. individual with full-time education and right-censored tenures after $t_{c}$ years: $T_{f}>t_{c}$ and ${ }^{i}<=i^{\circ} Z_{i}$

De.ning the dummy variable $\mathrm{I}_{2 \mathrm{i}}$ to indicate whether an individual's duration is known $\left(I_{2 i}=1\right)$ or whether it is right-hand censored $\left(I_{2 i}=0\right)$ and let $N$ be the number of observations, the basic form of the log likelihood function is as follows:

$$
\begin{aligned}
\log L & ={ }_{i=1}^{X} I_{1 i} I_{2 i} \log \left({ }_{1 i}\right)+\left(1_{i} I_{1 i}\right) I_{2 i} \log \left({ }_{2 i}\right) \\
& +I_{1 i}\left(1_{i} I_{2 i}\right) \log \left({ }_{3 i}\right)+\left(1_{i} I_{1 i}\right)\left(1_{i} I_{2 i}\right) \log \left({ }_{4 i}\right)
\end{aligned}
$$

Here $I_{k i}$, denotes the contribution to the likelihood function of individual $i$ who is in group $k, k=1 . .4$. The contribution to the likelihood function of person $i$ with part-time education and a completed tenure $t_{i}$ is: 


$$
\ddots_{1 i}={ }_{i{ }^{\circ} Z_{i}}^{Z_{1}} h_{p}\left(t_{i} ;{ }^{\prime} ;{ }^{1 / z_{p}}\right)
$$

This contribution can be written as (cf. Maddala, 1983, p. 272):

$$
\begin{aligned}
& { }_{1 i}=\underbrace{Z_{1}}_{i 1} h_{p}\left(t_{i} ;{ }_{i} ;{ }^{1 / z_{p}}\right) d^{d " i} i_{i 1}^{Z_{i}{ }^{\circ} Z_{i}} h_{p}\left(t_{i} ;{ }_{i} ;{ }^{1 / z_{p}}\right) d^{\prime \prime}{ }_{i}
\end{aligned}
$$

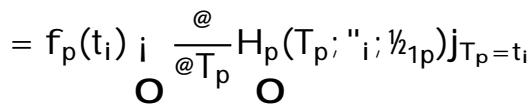

$$
\begin{aligned}
& =f_{p}\left(t_{i}\right) @ 1 ; @ \frac{d\left(i^{\circ} Z_{i}\right) i \frac{1 / z_{p}}{q} p\left(t_{i}\right)}{1 i^{1 / 2 / z p}} A A
\end{aligned}
$$

The contribution of the likelihood function of an individual i with full-time education and a completed tenure $t_{i}$ equals:

$$
\begin{aligned}
& i_{2 i}={ }_{i 1}^{Z_{i}{ }^{\circ} Z_{i}} h_{f}\left(t_{i} ;{ }_{i} ;{ }^{1 / 2 f}\right) \\
& =f_{f}\left(t_{i}\right) \odot @ \frac{J\left(i^{\circ} Z_{i}\right) i \frac{1 / 2 f}{q} f f\left(t_{i}\right)}{1 i^{1 / 2 / z f}} A
\end{aligned}
$$

Individuals with part-time education and right-hand censored tenures after $t_{c}$ years have the following contribution to the likelihood function:

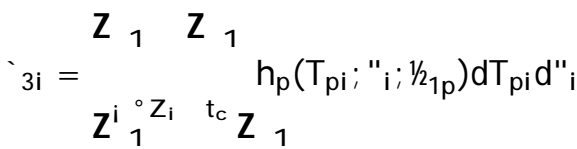

$$
\begin{aligned}
& =J_{\|\left(i^{\circ} Z_{i}\right) J_{p}\left(t_{c}\right)} b\left(\sum_{p i} ; i_{i} ; i^{1 / z_{p}}\right) d_{i p i} d_{n_{i}} \\
& =\mathrm{B}\left(\mathrm{i} J \mathrm{p}\left(\mathrm{t}_{\mathrm{c}}\right) ; \mathrm{i} J{ }\left(\mathrm{i}^{\circ} \mathrm{Z}_{\mathrm{i}}\right) ;{ }^{1 / z_{\mathrm{p}}}\right)
\end{aligned}
$$

Analogously, the log likelihood contribution of individuals with full-time education and right-hand censored tenures after $t_{c}$ years can be derived: 


$$
\begin{aligned}
& { }_{4 i}=Z_{i}{ }^{\circ} Z_{i} Z_{1} h_{f}\left(T_{f i} ;{ }_{i} ; 1 / \not \text { ff }\right) d T_{f i} d^{\prime \prime}{ }_{i}
\end{aligned}
$$

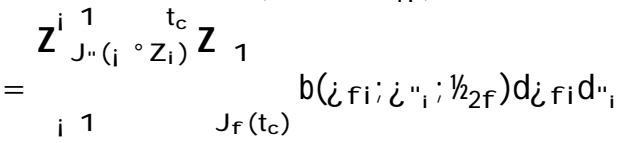

$$
\begin{aligned}
& =B\left(i J_{f}\left(t_{c}\right) ; j "\left(i^{\circ} Z_{i}\right) ; i \frac{1 / z f}{f f}\right.
\end{aligned}
$$




\section{A ppendix D: Econometric model tenure pub- lic auditing}

Let subscript $m$ refer to educational track with $m=f$ indicating full-time education and $m=p$ indicating the part-time NIvRA education. It is assumed that $T_{m p}$ and $T_{m l}$ have cumulative distribution functions:

$$
T_{m p} \gg F_{m p}\left(T_{m p}\right) \text { and } T_{m l} \gg F_{m l}\left(T_{m l}\right)
$$

Competing risks model are discussed in e.g. David \& Moeschberger (1978, chapter 4), and Card \& Olson (1995). There, the distribution functions of the durations are proposed to come from a relative simple distribution, like the multivariate normal distribution function, the multivariate log normal distribution function or the multivariate exponential distribution function. However, these distributions imply monotonous hazard functions which is not appropriate when the hazard rate behaves dixerently, like having one or more peaks.

Han and Hausman (1990) introduce a semiparametric estimation technique of the hazard functions. Their starting point is the destination speci..c proportional hazard speci..cation with $\mathrm{X}_{\mathrm{j} m}$ storing the explanatory variables for destination $n$ and, $0 j m\left(T_{j m}\right)$ being the baseline hazard function for destination $n$ :

$$
, \mathrm{mn}\left(\mathrm{T}_{\mathrm{mn}} ; \mathrm{X}_{\mathrm{mn}} ;{ }^{-}{ }_{\mathrm{mn}} ;, 0 \mathrm{mn}\right)=\exp \left(\mathrm{X}_{\mathrm{mn}}{ }^{-} \mathrm{mn}\right), 0 \mathrm{mn}\left(\mathrm{T}_{\mathrm{mn}}\right)
$$

In order to insure identi...cation no constant should be added to the model. This speci..cation yields the following linear relationships between the baseline integrated hazard function $x_{0 \mathrm{mn}}$ of $\mathrm{T}_{\mathrm{mn}}$ and the explanatory variables in case of two destinations:

$$
\text { i } \ln \left(\mathbb{x}_{0 m p}\left(T_{m p}\right)=X_{m p}{ }^{-} m p+" m p\right.
$$




$$
\mathrm{i} \ln \left(x_{0 \mathrm{ml}}\left(\mathrm{T}_{\mathrm{ml}}\right)=\mathrm{X}_{\mathrm{jl}}{ }^{-} \mathrm{ml}+{ }^{\prime \prime} \mathrm{ml}\right.
$$

Here, the random variables "mp and " $m$ l have a type I extreme value distribution, see for example K iefer (1988, p.664-665). In order to allow $\mathrm{T}_{\mathrm{mp}}$ and $\mathrm{T}_{\mathrm{ml}}$ to be correlated the random variables ${ }_{\mathrm{mp}}$ and $\mathrm{ml}_{\mathrm{m}}$ should be allowed to correlate and a bivariate extension of the type I extreme value distribution is needed. J ohnston and Kotz (1972) discuss some but they have the characteristic that they only allow for positive correlations which may not be appropriate. Han and Hausman propose to approximate the bivariate type I extreme value distribution by a bivariate normal distribution. This method allows for a negative correlation but unfortunately the approximation is of quite poor quality according to Sueyoshi (1992).

Like already mentioned in A ppendix C, Van Ophem and J onker (1997) propose to use a method suggested by Lee (1983) to correlate any two random variables by transforming them to the standard normal distribution. Starting from eqs. (2) and denoting the correlation between "mpand " $m \mathrm{l}$ by $1 / \mathrm{m}^{\prime \prime}$ yields:

$$
\begin{aligned}
& u_{m p}=J(" m p)=\bigodot{ }^{i}\left(F_{m p}\left("{ }_{m p}\right)\right) \\
& u_{m l}=J(" m l)=\bigodot{ }^{1}\left(F_{m l}(" m l)\right)
\end{aligned}
$$

where (.) ${ }^{1}($.$) is the inverse of the standard normal cdf and F($.$) denotes$ the cdf of the type I extreme value distribution. The transformed error terms $u_{m p}$ and $u_{m l}$ are standard normal distributed with correlation $1 / m_{n}$ : The bivariate distribution function having marginal $\mathrm{cdfs}_{\mathrm{mp}}\left(\mathrm{Fp}_{\mathrm{mp}}\right)$ and $\mathrm{F}_{\mathrm{ml}}\left({ }^{\mathrm{ml}}\right)$ and correlation $1 / \mathrm{m}^{\mathrm{n}}$ " between " $\mathrm{mp}$ and " $\mathrm{ml}$ and its corresponding bivariate density function are given by:

$$
\mathrm{H}\left(" \mathrm{mp} ; " \mathrm{ml} ;{ }^{1 / \mathrm{m}^{\prime}}\right)=\mathrm{B}\left(\mathrm{u}_{\mathrm{mp}}, \mathrm{u}_{\mathrm{ml}} ; 1 / 2\right)=\mathrm{B}\left(\mathrm{J}(" \mathrm{mp}) ; \mathrm{J}(" \mathrm{ml}) ; 1 / \mathrm{mu}_{\mathrm{u}}\right)
$$




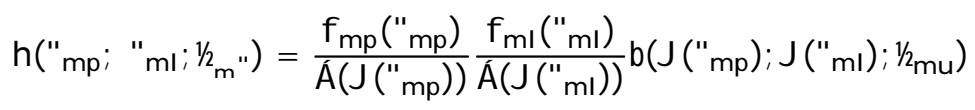

where $B(., ; 1 / 1 /$ nu $)$ is the bivariate normal cdf with zero means, unit variances and correlation $\frac{1}{m} \mathrm{~m}_{u} ; \mathrm{b}\left(.,, ; \frac{1}{\mathrm{~m} u}\right)$ is the accompanying bivariate normal df, $A(:)$ is the standard normal $d f$ and $f($.$) is the type I extreme value d f$.

The contributions to the likelihood function for the three dixerent groups of observations are given below. For people who become partner $t_{m p}$ years after becoming auditor the contribution to the likelihood function is as follows:

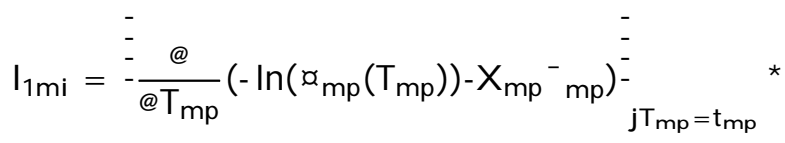

$$
\begin{aligned}
& f\left(-\operatorname{In}\left(x_{m p}\left(t_{m p}\right)\right)-X_{m p}{ }^{-} p\right) x
\end{aligned}
$$

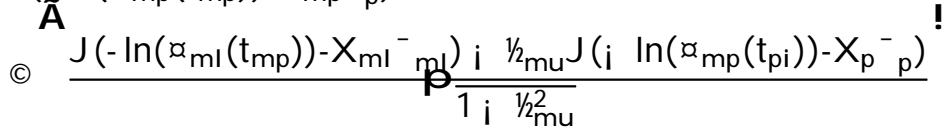

The contribution to the likelihood function for auditors who leave the accounting $t_{\mathrm{si}}$ years after becoming auditor is similar to the contribution to the likelihood function for those who become partner:

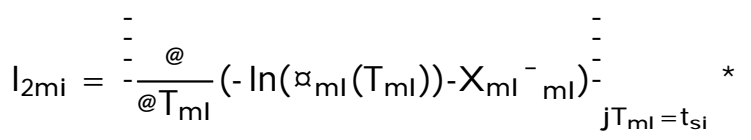

$$
\begin{aligned}
& \left.f\left(-{ }_{\tilde{A}} \ln \left(x_{m l}\left(t_{m l}\right)\right)-X_{m l}{ }^{-}\right)\right) \alpha
\end{aligned}
$$

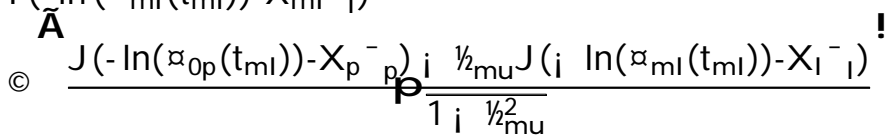

For the employees who are still working as non-partner at the accounting ..rm $t_{c i}$ ( $s o T_{p i}>t_{c i}$ and $T_{l i}>t_{c i}$ ) years after becoming auditor the likelihood contribution is:

$$
I_{3 m i}=B\left(J\left(i \ln \left(x_{0 p}\left(t_{c i}\right)\right) \text { i } X_{p}{ }^{-} p\right) ; J\left(i \ln \left(x_{01}\left(t_{c i}\right)\right) \text { i } X_{1}{ }^{-}{ }_{1}\right) ; 1 / m_{m u}\right)
$$


The log likelihood function of education $\mathrm{m}$ becomes

$$
\log L_{m}={ }_{i=1}^{N_{m}}\left(I_{1 i} \ln \left(I_{1 m i}\right)+I_{2 i} \ln \left(I_{2 m i}\right)+I_{3 m i} \ln \left(I_{3 m i}\right)\right)
$$

with the dummies $I_{1 \mathrm{mi}}, I_{2 m i}$ and $I_{3 \mathrm{mi}}$ equal to 1 if auditor $\mathrm{i}$ has education $\mathrm{m}$ and becomes partner, leaves the accounting ..rm without having become partner, respectively is still working at the ..rm as non-partner. $\mathrm{N}_{\mathrm{m}}$ denotes the number of observations with education $\mathrm{m}$.

The log likelihood can be maximized if the functional form of the hazard function is speci..ed. However, no standard speci..cation of the hazard function seems to be appropriate. Leaving the ..rm and becoming partner is concentrated at particular months in the year which causes peaks in the hazards. Van Ophem and J onker (1997) advise to use a semi-parametric speci..cation of the hazard function in case of multiple peaks. The integrated hazard function $\propto_{0 \mathrm{mn}}(T)$ is a non-decreasing function of $\mathrm{T}$ with $\varlimsup_{0 \mathrm{mn}}(0)=0$ : The real integrated hazard function is unknown but is approximated by a piecewise linear function. The range of durations is split up in $\mathrm{K}_{\mathrm{mn}}$ intervals and a constant hazard per interval is assumed. The resulting approximation of the integrated hazard function is a kinked line of connected line segments: where $K_{m n i}(<=K)$ is de..ned by

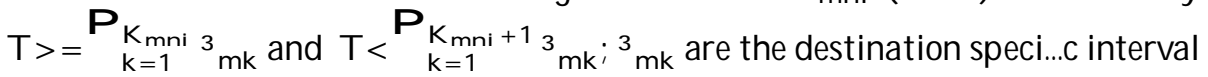
bounds with ${ }^{3}{ }_{\mathrm{m} 0}=0$ and $\mathbb{R}_{\mathrm{mnk}}(>=0)$ are the parameters to be estimated and equal to the constant hazard in interval $\left({ }^{3} \mathrm{mk}_{\mathrm{i}} ;{ }^{3}{ }_{\mathrm{mk}}\right]$ : Increasing the number of intervals increases the quality of the approximation. However, combining durations with few observations increases the reliability of the estimates. 


\section{R eferences}

\section{R eferences}

[1] Card, D. and C. A. Olson (1995), Bargaining Power, Strike Durations, and Wage Outcomes: An Analysis of Strikes in the 1880s, J ournal of Labor Economics, vol. 13(1), pp. 32-61.

[2] David, H. A., and M. L. Moeschberger (1978), The Theory of Competing Risks, Griф n's Statistical Monographs and Courses No. 39, Charles Griф n \& Company Ltd., London.

[3] Han, A. and J. A. Hausman (1990), F lexible parametric Estimation of Duration and Competing Risks M odels, J ournal of A pplied Econometrics, vol. 5, pp. 1-28.

[4] J ohnson, L. J . and S. Kotz (1972), Distributions in Statistics: Continuous Multivariate Distributions, vol. 4, J ohn Wiley $\&$ Sons, New York

[5] Kiefer, N. M . (1988), E conomic Duration Data and Hazard Functions, J ournal of Economic Literature, vol. 26(2), pp. 646-679.

[6] Lee, L. F. (1983), Generalized E conometric M odels with Selectivity, E conometrica 51, pp. 507-512.

[7] Maddala, G. S. (1983), Limited-Dependent and Qualitative Variables in E conometrics, Cambridge University Press, Cambridge.

[8] Ophem, H. van and N. J onker (1997), The Duration of Higher Education: Semiparametric Estimation of a Dependent Competing Risks M odel, working paper, A msterdam. 


\section{IZA Discussion Papers}

\begin{tabular}{|c|c|c|c|c|}
\hline No. & Author(s) & Title & Area & Date \\
\hline 624 & $\begin{array}{l}\text { J. Wagner } \\
\text { R. Sternberg }\end{array}$ & $\begin{array}{l}\text { Personal and Regional Determinants of } \\
\text { Entrepreneurial Activities: Empirical Evidence } \\
\text { from the REM Germany }\end{array}$ & 1 & $11 / 02$ \\
\hline 625 & F. Galindo-Rueda & $\begin{array}{l}\text { Endogenous Wage and Capital Dispersion, On- } \\
\text { the-Job Search and the Matching Technology }\end{array}$ & 3 & $11 / 02$ \\
\hline 626 & A. Kunze & $\begin{array}{l}\text { Gender Differences in Entry Wages and Early } \\
\text { Career Wages }\end{array}$ & 5 & $11 / 02$ \\
\hline 627 & $\begin{array}{l}\text { J. Boone } \\
\text { J. C. van Ours }\end{array}$ & Cyclical Fluctuations in Workplace Accidents & 5 & $11 / 02$ \\
\hline 628 & $\begin{array}{l}\text { R. Breunig } \\
\text { D. A. Cobb-Clark } \\
\text { Y. Dunlop } \\
\text { M. Terrill }\end{array}$ & $\begin{array}{l}\text { Assisting the Long-Term Unemployed: Results } \\
\text { from a Randomized Trial }\end{array}$ & 6 & $11 / 02$ \\
\hline 629 & $\begin{array}{l}\text { I. N. Gang } \\
\text { K. Sen } \\
\text { M.-S. Yun }\end{array}$ & Caste, Ethnicity and Poverty in Rural India & 2 & $11 / 02$ \\
\hline 630 & W. Arulampalam & $\begin{array}{l}\text { State Dependence in Unemployment Incidence: } \\
\text { Evidence for British Men Revisited }\end{array}$ & 3 & $11 / 02$ \\
\hline 631 & $\begin{array}{l}\text { H. O. Duleep } \\
\text { M. Regets }\end{array}$ & $\begin{array}{l}\text { The Elusive Concept of Immigrant Quality: } \\
\text { Evidence from 1970-1990 }\end{array}$ & 1 & $11 / 02$ \\
\hline 632 & $\begin{array}{l}\text { B. Cockx } \\
\text { M. Dejemeppe }\end{array}$ & $\begin{array}{l}\text { Duration Dependence in the Exit Rate out of } \\
\text { Unemployment in Belgium: Is It True or } \\
\text { Spurious? }\end{array}$ & 2 & $11 / 02$ \\
\hline 633 & A. D. Kugler & Employee Referrals and Efficiency Wages & 5 & $11 / 02$ \\
\hline 634 & $\begin{array}{l}\text { A. D. Kugler } \\
\text { R. M. Sauer }\end{array}$ & $\begin{array}{l}\text { Doctors Without Borders: The Returns to an } \\
\text { Occupational License for Soviet Immigrant } \\
\text { Physicians in Israel }\end{array}$ & 1 & $11 / 02$ \\
\hline 635 & $\begin{array}{l}\text { M. Karanassou } \\
\text { D. J. Snower }\end{array}$ & An Anatomy of the Phillips Curve & 3 & $11 / 02$ \\
\hline 636 & $\begin{array}{l}\text { M. Karanassou } \\
\text { H. Sala } \\
\text { D. J. Snower }\end{array}$ & $\begin{array}{l}\text { A Reappraisal of the Inflation-Unemployment } \\
\text { Tradeoff }\end{array}$ & 3 & $11 / 02$ \\
\hline 637 & $\begin{array}{l}\text { H. Bonin } \\
\text { W. Kempe } \\
\text { H. Schneider }\end{array}$ & $\begin{array}{l}\text { Household Labor Supply Effects of Low-Wage } \\
\text { Subsidies in Germany }\end{array}$ & 3 & $11 / 02$ \\
\hline 638 & $\begin{array}{l}\text { L. McLeod } \\
\text { M. R. Veall }\end{array}$ & $\begin{array}{l}\text { The Dynamics of Food Deprivation and Overall } \\
\text { Health: Evidence from the Canadian National } \\
\text { Population Health Survey }\end{array}$ & 2 & $11 / 02$ \\
\hline 639 & G. Saint-Paul & Are Intellectual Property Rights Unfair? & 3 & $11 / 02$ \\
\hline 640 & $\begin{array}{l}\text { J. Hartog } \\
\text { N. Jonker } \\
\text { H. van Ophem }\end{array}$ & $\begin{array}{l}\text { Dual Track or Academic Route for Auditors: } \\
\text { Does It Matter? }\end{array}$ & 6 & $11 / 02$ \\
\hline
\end{tabular}

